\title{
Hükümlerin Dayandığı Delillerde Kesinliği Öngören Fıkıh Kâidelerinin Hadislerdeki Temelleri
}

\section{Dr. Serkan ÇELIIKAN*}

Atıf / @-- Çelikan, S. (2018). Hükümlerin Dayandığı Delillerde Kesinliği Öngören Fıkıh Kâidelerinin Hadislerdeki Temelleri, Çukurova Üniversitesi İlahiyat Fakültesi Dergisi, 18 (1), 361-389.

Öz- İslâm fıkhında, ibadetlerden hukukî süreçlere kadar bütün beşerî faaliyetlerde, kararlar üzerinde belirleyici olan bilgi ve delillerin kesin nitelikli olması esastır. Bu, doğru ve adil sonuçlara varabilmenin önemli bir şartıdır. Dolayısıyla şüphenin ve farklı ihtimallerin varlığından kurtulamamış delillerin karar vermede ve hüküm tesisinde dayanak olarak görülmesi mümkün olmamaktadır. Bu önemli husus fıkıh kâideleri (kavâid-i fıkhiyye) olarak da bilinen İslâm hukukunun temel prensipleri arasında da çeşitli maddeler aracılığıyla yerini bulmuştur. Hz. Peygamber (a.s.) devrinin İslâm hukukunun ilk uygulama alanı olduğu dikkate alındığında bahsi geçen ilkenin ve dolayısıyla bu ilkeyi farklı formlarda ortaya koyan fıkıh kâidelerinin temellerinin de bu dönemde mevcut bulunabileceğini tahmin etmek zor olmaz. Nitekim hadis kaynaklarında yapılan incelemeler şüphe-hüküm ilişkisi olarak da isimlendirilebilecek bu konuda kavlî ve fiilî sünnetten çeşitli örneklerin bulunduğunu ortaya koymaktadır. Bu çalışma söz konusu örneklerin tespitini, sıhhat durumlarını ve mevzu bahis olan esasla ilgilerini belirlemeyi amaçlamaktadır.

Anahtar sözcükler- İslâm fıkhı, fıkıh kâideleri, hadis kaynakları, sünnet, şüphe-hüküm ilişkisi

\section{$\S \S \S$}

\section{Giriş}

Konuyla ilgili görülen rivayetleri incelemeye başlamadan önce araştırmanın temel kavramlarından "fıkıh kâideleri" hakkında bilgi vermek faydalı olacaktır.

Makalenin gelişi: 25.04.2018; Yayına kabul tarihi: 12.06.2018

* Milli Eğitim Bakanlığı Kadirli Fen Lisesi Din Kültürü ve Ahlak Bilgisi Öğretmeni, e-posta: serkancelikan@hotmail.com (ORCID: 0000-0001-6469-9533) 
Fıkıh kâideleri, farklı ve çeşitli, ancak birbirine benzeyen cüz'î hükümleri kapsamına alan genel kâidelerdir. ${ }^{1}$ Bunlar İslâm fıkhının genel kuramları olarak da isimlendirilir. Örneğin İslâm şeriatındaki mülkiyet ve tazminat hukuku ile ilgili kâidelerde olduğu gibi, aralarında benzerlik olan birçok hüküm vardır ki bunları birbirine bağlayan bir tek kural bulunmaktadır. ${ }^{2}$ İşte bu kurallar İslâm fıkhının hükümlerini toplu olarak ifade etmeleri nedeniyle "kavâid-i fıkhiyye" olarak isimlendirilmişlerdir. ${ }^{3}$

Karâfî (ö. 684/1285), el-Furûk adlı eserinde fıkıh kâideleri ile ilgili bilgi vermektedir. O, öncelikle Hz. Peygamber'in şeriatının usûl ve füru olmak üzere iki bölümden meydana geldiğini belirtmiş ve usûlün de kendi içinde yine ikiye ayrıldığını ifade etmiştir. ${ }^{4}$ Usûlün bu iki kısmı ile ilgili olarak da şu açıklamayı yapmıştır: "Bunlardan ilki usûl-i fıkıh olarak isimlendirilir. Bu ilim genel yapısı itibariyle, bilhassa bazı Arapça lafız ve ifadelerden kaynaklanan hükümlerle ilgili kâideleri ve bu lafızlar için söz konusu olan nesh ve tercih gibi durumları inceler. Buna örnek olarak, 'Emir farziyet, nehiy haramlık, hususiyet ifade eden kipler de genellik anlamındadır vb.' kâideler zikredilebilir. Bu türün dışında ise sadece kıyasın hüccet oluşu, haber-i vâhid ve müctehidlerin vasıfları gibi konular bulunmaktadır. Usûlün ikinci kısmını ise, pek değerli ve mühim, sayıca çok, fıkha büyük destek ve olanaklar sunan, şeriatın sırlarını ve hikmetlerini ihtiva eden küllî/fıkhî kâideler oluşturur. Her bir kâidenin altında, şeriatın ferî meselelerinden oluşan sayılamayacak kadar çok örnek bulunmaktadır. Oldukça özet bir şekilde işaret edildiğinde görüş ayrılığı bulunma-

1 Fıkıh kâidelerinin nitelikleri ve faydaları ile ilgili kapsamlı bir değerlendirme için bkz. Burnû, Muhammed Sıdkî b. Ahmed, Mevsûatü'l-kavâidi'l-fıkhiyye, I-XII, Mektebetü't-Tevbe/Dâru İbn Hazm/Müessesetü'r-Risâle, Riyad/Beyrut, 1997/1418, 2000/1421, 2003/1424, I, 29-31.

2 Bkz. İbn Selâme, Ebû İslâm Mustafa b. Muhammed, et-Te'sîsu fî usûli'l-fıkhi alâ dav'ï'l-kitâbi ve's-sünneti, Mektebetü'l-Harameyni li'l-Ulûmi'n-Nâfia, byy., trs., s. 17. Bu alanda yazılmış eserlere, Ebû Zeyd Debûsî'nin (v. 430/1039) Te'sîsu'n-nazar, İzzeddin b. Abdüsselâm'ın (v. 660/1262) Kavâidu'l-ahkâm, Karâfî'nin (v. 684/1285) el-Furûk, Takıyyuddin İbn Teymiyye'nin (v. 728/1328) el-Kavâidu'n-nûrâniyye, Tâcüddin Sübkî̀nin (v. 771/ 1370) el-Eşbâh ve'nnezâir, İbn Receb'in (v. 795/1393) el-Kavâidu fî'l-fıkhi'l-İslâmî, Suyûtî'nin el-Eşbâh ve'n-nezâir fî kavâidi ve furûi fıkhi'ş-Şâfiiyye, İbn Nüceym'in (v. 970/1563) el-Eşbâh ve'n-nezâir, Ebû Saîd el-Hâdimî'nin (v. 1176/1762) Mecâmiu'l-hakâik, muasır âlimlerden Ahmed Muhammed Zerkâ'nın Şerhu'l-kavâidi'l-fıkhıyye, Ali Ahmed Nedvî'nin el-Kavâidu'l-fıkhiyye ve Abdulkerim Zeydân'ın el-Vecîz fî şerhi'l-kavâidi'l-fıkhiyye fíş̧-şerîati'l-Islâmiyye adlı eserleri örnek verilebilir.

3 Karâfî bu kavramı "küllî" olma vasfını da ekleyerek قواعد كلية فقهية "Kavâidu Külliyye Fıkhiyye" terkibi ile ifade etmiştir ki aynı anlamda kullanıldıklarını gösterir. Bkz. Karâfî, Şihâbuddin Ebû'l-Abbâs Ahmed b. İdrîs el-Mısrî el-Mâlikî, el-Furûk, I-IV, thk. Ömer Hasen el-Kıyyâm, Müessesetü'r-Risale, Beyrut 1424/2003, I, 62. Mecelle'nin matbu nüshalarında ise görüldüğü kadarıyla "Kavâidu Fıkhiyye" terkibi tercih edilmiştir. Bkz. Mecelle-i Ahkâm-ı Adliyye Cemiyeti, Mecelle-i Ahkâm-i Adliyye, Matbaa-i Osmaniye, İstanbul 1300/1882, s. 22. Ancak "kâide" kavramının muhtevasındaki "külli” olma niteliği göz önünde bulundurulduğunda kavramın bir de "küllî" sıfatı ile tavsif edilmesinin zaid olduğu akla gelebilir.

4 Karâfî, el-Furûk, I, 62. Ayrıca bkz. Zerkâ, Ahmed b. Muhammed, Şerhu'l-kavâidi'l-fıkhıyye, thk. Mustafa Ahmed Zerkâ, Dâru'l-Kalem, Dımeşk, 1409/1989, s. 35. 
makla beraber, usûlü fıkıhta bu kâidelerle ilgili herhangi bir şey zikredilmemiş ve böylece (bu ilim açısından) bunların tafsilatı ile ilgili bir bilgiye sahip olunamamıştır."5

"Kavâid-i fıkhiyye" nin ıstılahî anlamı ile ilgili olarak, muasır âlimlerden أصول فقهية كلية في نصوص موجزة دستورية:Mustafa Ahmed ez-Zerkâ'nın ifadeleri ise şöyledir "Yasal nitelikli kısa metinler şeklinde ifade edilen, kendi mevzusunun kapsamına giren olaylar hakkında genel/kapsamlı teşriî hükümler içeren fıkhî-küllî asıllardır."' Zerkâ bu tanımı genişletmek üzere de şöyle demiştir: "Fıkıh kâideleri, manalarının genel olması ve ferî//cüz'î konuları içermeleri açısından geniş kapsamlı olmalarına rağmen ibarelerinde oldukça kısa ve öz olmalarıyla farklılık gösterirler. Zira bazı kâideler, umûmî lafızlardan (seçilmiş), açık ve kesin anlamlı iki veya daha fazla (ancak az sayıda) kelimeden oluşur."7

Modern İslâm hukukçularından Ali Ahmed en-Nedvî ise kavram ile ilgili iki ayrı tanım yapmıştır ki birincisi şudur: حكم شرعي في قضية أغلبية يتعرف منها أحكام ما دخل تحتها "Kendi kapsamına giren ferî meselelerin hükümlerini bilmeye yarayan, ağlebî/baskın bir önerme şeklinde ifade edilen şerî hükümdür."8 en-Nedvî bu tanımın izahı sadedinde de şöyle demektedir: "Kavâid-i fıkhiyye, müşterek fıkhî bir yönden birbirleri ile bağlantıları bulunan, çeşitli konularla ilgili bir grup şer'î hükmü ihtiva eden kâidelerdir. Böylece tarifte zikredilen 'şer'î' kaydı, şer'î olmayanları kapsamdan çıkarmaktadır. 'Ağlebiyye' şeklindeki ikinci kayıt da, bu kâidelerin çoğunluk/baskınlık özelliği ile nitelendirildiğini ifade etmektedir. Çünkü birçok kâidenin, kendisine aykırı düşen bazı ferî̀ meseleleri vardır. Bu ferî̀ meselelerin kapsamdan çıkması, kâidelerin umumî olma vasfını değiştirmez ve onların değerini düşürmez."9

Bazı fer'î meselelerin, kendileri ile ilgili küllî kâidelerin muhtevası dışında kaldıkları, dolayısıyla bu kâidelerin genel kapsamlı değil de çoğunluk meseleler için geçerli olduğu şeklindeki Nedvî'nin işaret ettiği bilgiye Mustafa

5 Karâfî, el-Furûk, I, 62. Ayrıca bkz. Zerkâ, Şerhu'l-kavâidi'l-fıkhıyye, s. 35-36. Usûl kâideleri ile fıkıh kâideleri arasındaki farkla ilgili kapsamlı bilgi için bkz. Bâ Hüseyin, Yakûb b. Abdülvehhâb, el-Kavâidu'l-fıkhiyye, Mektebetü'r-Rüşd/Şeriketü'r-Riyâd, Riyâd 1418/1998, s. 135-142; Burnû, Mevsûatü'l-kavâidi'l-fıkhiyye, I, 25-28.

6 Bkz. Zerkâ, Şerhu'l-kavâidi'l-fıkhıyye, s. 34.

7 Bkz. Zerkâ, Şerhu'l-kavâidi'l-fıkhıyye, s. 34.

8 Nedvî, Ali Ahmed, el-Kavâidu'l-fıkhiyye, tkd. Mustafa ez-Zerkâ, Dâru'l-Kalem, Dımeşk 1412/1991, s. 43.

9 Nedvî, el-Kavâidu'l-fıkhiyye, s. 43. Kâidelerin umûmî olma özelliği ile ilgili olarak Ömer Nasuhi Bilmen de şu değerlendirmede bulunmuştur: "Vâkı bu kâidelerin dâire-i ihâtalarından müstesna bazı meseleler vardır. Fakat bu kâideler, esasen birbirini takyid, tahsis ve bu cihetle ikmal etmekte bulunmuş olduğundan yine birer kâide-i külliyye olmaları mahfuz bulunmuştur." Bkz. Bilmen, Ömer Nasuhi, Hukuku İslamiyye ve Istılâhâtı Fıkhiyye Kâmûsu, I-VIII, Bilmen Yayın Evi, İstanbul 1967, I, 254. 
Ahmed Zerkâ da, Mecelle'nin bu konudaki tutumu bağlamında temas etmektedir. Buna göre hâkimlerin, vermiş oldukları hükümlerde, yargı konusu olan olayla ilgili özel veya genel bir başka nassa bakmaksızın sadece küllî kâidelere dayanmakla kendilerini sınırlandırmalarına Mecelle müsaade etmemiştir. Çünkü bu küllî kâidelerin, değer ve itibarına rağmen birçok istisnası da vardır. Ayrıca bunlar fıkhın genel kuralları olup, yargı metinleri değildir. ${ }^{10}$

أصل فقهي كلي يتضمن أحكاما تشريعية عامة من أبواب: Nedvî’nin ikinci tanımı ise şudur "Hukukun çeşitli alanlarının, kendi mevzusuna giren meseleleri ile ilgili, yasama nitelikli genel hükümler içeren fıkhî ve küllî asıldır."11

Nedvî'nin yaptığı bu iki tanımın esasta birbirinden farklı olmadığı söylenebilir. Şu var ki birinci tanımda fıkhî asılların ağlebî yani ilgili konunun çoğunluk meselelerini içerdiği vurgulanırken ikinci tanımda bu asılların külî̂lik/genel kapsamlılık niteliğine vurgu yapılmıştır. Ayrıca birinci tanımda ikinciden fazla olarak fıkhî asılların fonksiyonuna yer verilmiştir ki bu da meselelerin ayrıntıları ile ilgili hükümlerin bilinip ortaya çıkarılmasıdır.

Ömer Nasuhi de, "kavâid-i fıkhiyye"nin İslâm hukukunun usûlü mesabesinde olduğunu ve bunların her birinin bir şer'î delile dayandığını belirtmiştir. Yine onun ifadesiyle bunların bir çoğu çeşitli şer'î delillerin tetebbu ve istikrası neticesinde elde edilmiş olmaları açısından yalnız muayyen bir şer'î delilden alınan kâidelerden daha kuvvetlidir. ${ }^{12}$ Ömer Nasuhi, bu kâidelerin "küllî/genel" olarak nitelendirilmesinin sebebini de bunların her birinin pek kapsamlı birer esas olup başka kâidelerin çerçevesine dahil bulunmamaları ile izah etmiştir. ${ }^{13}$

10 Bkz. Zerkâ, Şerhu'l-kavâidi'l-fıkhıyye, s. 34.

11 Nedvî, el-Kavâidu'l-fıkhiyye, s. 45.

12 Bkz. Bilmen, Kâmûs, I, 254. Ayrıca bkz. Erdoğan, Mehmet, Fıkıh ve Hukuk Terimleri Sözlüğü, Rağbet Yay., İstanbul 1998, s. 235.

13 Bkz. Bilmen, Kâmûs, I, 254. Kavramın zikredilen tanımlarla örtüşen diğer tanımları için bkz. Bâ Hüseyin, el-Kavâidu'l-fıkhiyye, s. 54; Baktır, Mustafa, "Kâide", DiA, XXIV, ss. 205-210, İstanbul 2001, XXIV, 205. Fıkıh kâidelerinin değer ve önemi hakkındaki bir değerlendirmeyi de Karâfî, yine el-Furûk adlı eserinde şu şekilde yapmıştır: "Bu kâidelerin fıkıh ilmindeki önemi ve faydası çok büyüktür. Fakihin değeri ve mertebesi, bunları bildiği oranda artar ve yine bu oranda fıkhın parlaklığı ortaya çıkar ve bilinir; fetvânın yolları ve yöntemleri açıklığa kavuşur. Ilim ve irfan sahipleri bu alanda birbirleriyle yarışmışlar ve neticede bu konuda kabiliyetli olanlar böyle olmayanlara üstün gelmişler ve büyük bir başarı örneği sergilemişlerdir. Kavâid-i külliyyeyi ihmal ederek sadece cüz'î bağıntılar aracılığı ile fer'î meselelerin hükmünü bulmaya çalışan kimse için ise, bu fer'î meseleler birbiriyle çelişkili, karışık ve düzensiz bir görünüm arz eder ve böyle birinin zihni ve düşüncesi sarsılır; bu nedenle yüreği daralır ve ümitsizliğe kapılır. Neticede bu kimse bitmez tükenmez cüz'î meseleyi ezberleme ihtiyacı duyar. Böylece ömür biter ancak o henüz arzularını gerçekleştirememiştir. Fıkhı, kâideleri ile beraber öğrenen kimse ise, bu küllî kâidelerin kapsamına girmesi nedeniyle, birçok cüzî̀ meseleyi ezberleme gereksinimi duymaz ve başkaları açısından birbirine zıt, karışık ve düzensiz görünen meseleler onun açısından birlik, düzen ve uyum içerisinde görünür. Büyük farklılıklar, ona göre birbiriyle uyuşur ve yakınlaşır. En kısa zamanda isteklerini elde eder. Beyânın nurunun, üzerinde parıldamasıyla gönlü 
Bu tanımlar ve kavramın niteliği ile ilgili verilen bilgilerden yola çıkarak "kavâid-i fıkhiyye" kavramı hakkında özetle şunlar söylenebilir:

a) İslâm hukukunun bazı bölümlerinin üzerine tesis edildiği yasal nitelikli temel kurallardır.

b) Oldukça veciz, ancak kapsamlı ifadelerden oluşmaktadırlar.

c) Bir veya birden fazla şer'î delilden tümevarım yöntemiyle elde edilmektedirler.

d) Geniş kapsamlı olmaları nedeni ile başka kâidelerin içeriğine dâhil olmadıkları için "küllî" olma özelliğini kazanmışlardır.

e) İlgili olduğu konunun ferî̀ meselelerinin bütününü veya çoğunluğunu kapsaması yönüyle, bunların sayesinde birçok yeni hadisenin de hükmünü belirlemek mümkün olmaktadır.

Fıkıh kâideleri hakkındaki bu genel bilgilerden sonra araştırma konusu ile ilgili kâideler, bunların kayıtı bulundukları fıkıh eserleri ve taşıdıkları anlamlar hakkında bilgi verilebilir. Özellikle anlamları hakkında verilecek bilginin, kâidelerin esası olarak tespit edilen rivayetlerle kâideler arasındaki ilginin belirlenmesine ve böylece konunun anlaşılmasına katkı sunacağı düşünülmektedir.

\section{Hükümlerin Dayandığı Delillerde Kesinliği Öngören Kâideler, Kayıtlı Bulundukları Fıkıh Eserleri ve Anlamları}

Araştırma konusunun kapsamı içerisinde değerlendirilen fıkıh kâideleri çeşitli eserlerde farklı formlar ile kaydedilmiştir. Bunların belli başılarını şöyle sıralamak mümkündür:

a) Şek ile yakîn zâil olmaz.

b) Yakîn ile sabit olan şey ancak yakîn ile ortadan kalkar.

c) Yakîn ile sabit olan şey şüphe ile ortadan kalkmaz.

d) Hatâsı zâhir olan zanna i’tibâr yoktur.

e) Senede müstenid olan ihtimâl ile hüccet yoktur.

f) Tevehhüme i'tibâr yoktur.

İlk olarak zikredilen, "Şek ile yakîn zâil olmaz." kâidesi İslâm hukukunun kaynaklarından "istishâb" ile de ilgili olarak eşyada ve hadiselerde devam-

ferahlar. Bu iki konum arasında ise uzak bir mesafe ve ciddi bir tezat vardır." Bkz. Karâfî, elFurûk, I, 62-63. Ayrıca bkz. Zerkâ, Şerhu'l-kavâidi'l-fıkhıyye, s. 36; Zuhaylî, Muhammed Mustafa, el-Kavâidu'l-fıkhiyye ve tatbîkâtuhâ fîl'-mezâhibi'l-erbaa, I-II, Dâru'l-Fikr, Dımaşk 1430/2009, I, 26-27; Burnû, Mevsûatü'l-kavâidi'l-fıkhiyye, I, 8. 
Iılığı öngören kâideler olarak değerlendirilen kâideler grubu ${ }^{14}$ içerisinde de mütalaa edilmektedir. Ancak muhtevası itibariyle yukarıdaki gibi bir grubun içersisinde yer alması da mümkündür. Nitekim Ali Şafak'ın Mecelle'de yer alan fıkıh kâideleri hakkında yaptığı tasnif de bu yöndedir. ${ }^{15}$ Ayrıca Refik Gür de bununla uyumlu olarak kâidenin, "Tevehhüme i'tibâr yokdur." kâidesi ile ilgili olduğunu belirtmiş ve inceleme neticesinde kanaat getirilen ve sabit görülen bir hukukî durum ve hakikat karşısında bunun hilâfına veya aksine ihtimaller düşünülerek hükümden vazgeçilip, ihtimaller üzerine karar verilmesinin câiz olmadığını ifade etmiştir. ${ }^{16}$

Mezkûr kâide Sübkî'nin (ö. 771/1370), Süyûtî’nin (ö. 911/1505) ve İbn Nüceym'in (ö. 970/1563) el-Eşbâh ve’n-nezâirlerinde, اليقين لا يزال بالشك "Şek ile yakîn zâil olmaz." şeklindeki metinle yer almaktadır. ${ }^{17}$ Yukarıda ikinci olarak zikredilen kâideyi ise Süyûtî Şâfiî’ye nispet etmiştir ki öncekine benzemektedir. Bu kâidenin metni de, ما ثبت بيقين لا يرتفع إلا بيقين "Yakîn ile sabit olan şey ancak yakîn ile ortadan kalkar." şeklindedir. ${ }^{18}$ İbn Nüceym'in de kaydettiği ${ }^{19}$ bu kâidenin diğerinin farklı bir ifadesi olup anlam yönüyle aynı oldukları da söylenebilir. Yukarıda üçüncü sırada zikredilen kâide de yine öncekilere benzer bir metne sahip olup daha eski kaynaklardan Ebû'l-Hasen el-Kerhî'nin Risâle'sinde, إن ما ثبت باليقين لا يزول بالشك "Yakîn ile sabit olan şey şüphe ile ortadan kalkmaz." şeklindeki lafızlarla kayıtlıdır. ${ }^{20}$ Yine Serahsî'nin Usûfünde ve elMebsût unda da kâide yukarıda ilk olarak zikredilen metin ile yer almaktadır. ${ }^{21}$ İmam Nesefî de bu kâide ile ilgili olarak, abdest aldığını kesin olarak bilen bir kişinin, bozduğu konusunda şüphe etmesi durumunda, bozduğuna dair kesin

14 Bu kâideler için bkz. Mecelle, (mad. 5, 6, 8, 9, 10, 11, 55, 56), s. 22, 23, 29.

15 Şafak, Ali, "Hukukun Temelleri Açısından Mecelle'ye Bir Bakış", Ahmet Cevdet Paşa (18231895), (Sempozyum: 9-11 Haziran 1995), TDV Yay., ss. 263-278, Ankara 1997, s. 265.

16 Gür, A. Refik, Hukuk Tarihi ve Tefekkürü Bakımından Mecelle, Sebil Yay., İstanbul 1993, s. 117.

17 Sübkî, Tâcüddin Abdulvehhâb b. Ali b. Abdulkâfî, el-Eşbâh ve'n-nezâir, I-II, thk. Âdil Ahmed Abdulmevcûd, Dârü'l-Kütübi'l-IIlmiyye, Beyrut 1411/1991, I, 24; Süyûtî, Celaleddin Abdurrahman, el-Eşbâh ve'n-nezâir fî kavâidi ve furûi fıkhi'ş-Şâfiiyye, I-II, Mektebetü Nizâr Mustafa el-Bâz, Mekke/Riyâd 1418/1997, I, 86; İbn Nüceym, Zeynuddin b. İbrahim b. Muhammed, el-Eşbâh ve'n-nezâir, thk. Muhammed Mutî' el-Hâfız, Dâru'l-Fikr, Dımeşk 1983, s. 60. Ayrıca bkz. Mecelle, (mad. 4), s. 22; Mesûd Efendi, Mirât-ı Mecelle, Matbaa-i Osmaniye, Dersaâdet 1302/1884, s. 13; Bilmen, Kâmûs, I, 256; Öztürk, Osman, Osmanlı Hukuk Tarihinde Mecelle, İslâmî İlimler Araştırma Vakfı Neşriyatı, İstanbul 1973, s. 123.

18 Bkz. Süyûtî, el-Eşbâh ve'n-nezâir, I, 97.

19 Bkz. İbn Nüceym, el-Eşbâh ve'n-nezâir, s. 64.

20 Debûsî, Ebû Zeyd Ubeydullah b. Îsâ el-Hanefî, Te'sîsu'n-nazar, thk. Mustafa Muhammed elKabbânî ed-Dımeşkî, Dâru İbn Zeydûn, Beyrut/Mektebetü'l-Külliyyâti'l-Ezheriyye, Kahire trs., s. 161. Ayrıca bkz. Pezdevî, Ali b. Muhammed el-Hanefî, Kenzu'l-vusûl ilâ ma'rifeti'l-usûl, Matbaatu Câvîd Büryes, Karaçi trs., s. 367; Bâ Hüseyin, el-Kavâidu'l-fıkhiyye, s. 220.

21 Serahsî, Muhammed b. Ahmed, Usûlü's-Serahsî, I-II, Dâru'l-Kütübi'I-İlmiyye, Beyrut 1414/1993, II, 116; a.mlf. el-Mebsût, I-XXX, Dâru'I-Ma'rife, Beyrut 1414/1993, III, 64. 
kanaat sahibi olmadıkça abdestli sayılacağı, aynı şekilde abdestini bozduğunu kesin olarak biliyorsa, abdestli olduğu hususunda tereddüt yaşaması halinde de bu kişinin abdest aldığına dair kesin kanaat sahibi olmadığı sürece abdestsiz sayılacağı ${ }^{22}$ yönünde bir örnek zikretmiştir ki aşağıda bununla ilgili bir rivayete yer verilecektir.

Dördüncü kâide de yine Süyûtî'nin ve İbn Nüceym'in el-Eşbâh ve'nnezâirlerinde ve Hâdimî'nin Mecâmi’inde, لا عبرة بالظن البين خطؤه şeklindeki metin ile kayıtıdır. ${ }^{23}$ Kâidenin anlamı ile ilgili olarak, zanna göre yapıldıktan sonra şer'î hükme aykırı olduğu ortaya çıkan bir fiile itibar edilmemesi gerektiği yönünde bir açıklama yapılmıştır. ${ }^{24}$ Yine hata ister açık ve o an mevcut bulunsun isterse de gizli olup sonradan belirsin bunun sonucunda verilen hükmün ilga edilip yok hükmünde sayılacağı da ifade edilmiştir. ${ }^{25}$ Buna örnek olarak da, bir kimsenin bir başkasına borcu olduğunu söyleyip ona bir şeyler verdikten sonra aslında borcu olmadığının ortaya çıkması durumunda verdiği şeyleri geri alabilmesinin mümkün olduğu zikredilmektedir. ${ }^{26}$

Beşinci kâide ise Hâdimî'nin Mecâmi’indeki, لا حجة مع الاحتمال الناشئ عن دليل kâidesinden iktibas edilmiştir. ${ }^{27}$ Mesûd Efendi bu kâidenin özellikle itikâdî konularda geçerli olduğunu belirtmek suretiyle farklı bir alana atıfta bulunmuştur. Yine onun ifadesiyle bu türden konular yakînî bilgiyi gerektirdiğinden intimalli delillerle sabit olamazlar. ${ }^{28}$ Fer'î meselelerden verdiği örnek ise ölüm hastalığındaki bir kimseden, vârislerinden biri lehine sadır olan borç ikrarının sahih olmamasıdır. Ancak bazı vârislerin onaylaması halinin bundan müstesna olduğu da yine kendisi tarafından belirtilmiştir. ${ }^{29}$ Ali Haydar Efendi'nin bu örnek ile ilgili sözleri ise daha açıklayıcıdır. Buna göre kişinin hastalık hali,

22 Debûsî, Te'sîsu'n-nazar, s. 161. Ayrıca bkz. Pezdevî, Kenzu'l-vusûl ilâ ma'rifeti'l-usûl, s. 367. Süyûtî bunu, "Bir şeyin bulunduğu hâl üzre kalması asldır." kâidesinin örneği olarak zikretmiştir. Bkz. Süyûtî, el-Eşbâh ve'n-nezâir, I, 91. Ayrıca bkz. Zuhaylî, el-Kavâidu'l-fıkhiyye, I, 130.

23 Süyûtî, el-Eşbâh ve'n-nezâir, I, 253; İbn Nüceym, el-Eşbâh ve'n-nezâir, s. 188; Hâdimî, Ebû Saîd Muhammed, Mecâmiu'l-hakâik, Mahmud Bey Matbaası, byy., 1318, s. 370. Ayrıca bkz. Mecelle, (mad. 72), s. 32; Ali Haydar, Dürerül-hükkâm şerhu Mecelleti'l-ahkâm, I-IV, Dâru Âlemi'l-Kütüb, Riyad 1423/2003, I, 72; Mesûd Efendi, Mir'ât-ı Mecelle, s. 31; Bilmen, Kâmûs, I, 279; Öztürk, Osmanlı Hukuk Tarihinde Mecelle, s. 130.

24 Bkz. Ali Haydar, Dürerü'l-hükkâm, I, 72.

25 Bkz. Zerkâ, Şerhu'l-kavâidi'l-fıkhıyye, s. 357.

26 Bkz. Bilmen, Kâmûs, I, 279; Zerkâ, Şerhu'l-kavâidi'l-fıkhıyye, s. 358. Diğer bazı örnekler için bkz. Süyûtî, el-Eşbâh ve'n-nezâir, I, 253-254.

27 Hâdimî, Mecâmi', s. 370. Ayrıca bkz. Mecelle, (mad. 73), s. 32; Ali Haydar, Dürerü'l-hükkâm, I, 73; Mesûd Efendi, Mir'ât-ı Mecelle, s. 32; Bilmen, Kâmûs, I, 279; Öztürk, Osmanlı Hukuk Tarihinde Mecelle, s. 130.

28 Bkz. Mesûd Efendi, Mir'ât-ı Mecelle, s. 32.

29 Bkz. Mesûd Efendi, Mirât-ı Mecelle, s. 32. Ayrıca bkz. Yıldırım, Mustafa, Mecelle'nin Küllî Kâideleri, İzmir İlahiyat Fakültesi Vakfı Yay., İzmir 2001, s. 158. 
onun bu borç ikrarı ile diğer vârislerini mirastan mahrum etme maksadını gütmüş olma ihtimalini ortaya çıkarmaktadır. Fakat sağlıklı iken yapmış olduğu böyle bir ikrar geçerlidir. Çünkü bu durumda onun diğer vârisleri mirastan mahrum etme arzusunda olma intimali, sadece ihtimal ve bir tür vehim ve zan olması yönüyle ikrarın geçerliliğine engel teşkil etmez. ${ }^{30}$ Hastanın, vârisi olmayanlara yaptığı borç ikrarı ise her zaman geçerlidir. Çünkü onun yabancılara, vasiyet yoluyla da menfaat ulaştırma imkânı vardır. Dolayısıyla vârisler hakkında geçeli olan ihtimaller onlar hakkında geçerli değildir. Bu nedenle de onlar hakkında yapılan ikrar sahih ve muteberdir. ${ }^{31}$

Altıncı olarak zikredilen, لا عبرة للتوهم kâidesinin ise başta Mecmau'lfetâvâ olmak üzere birçok fıkıh kitabında zikredildiği Ali Haydar Efendi tarafından belirtilmiştir. ${ }^{32}$ Yine onun ifadesiyle kâide, hiçbir şer'î hükmün vehme dayalı olarak sabit olamayacağı anlamı yanında, sabit olan bir şeyin sonradan ortaya çıkan bir vehim sebebi ile ertelenmesinin kati surette caiz olamayacağı anlamına da gelmektedir. ${ }^{33}$

Netice itibariyle, mevzu bahis olan bu külî kaidelerin bir açıdan anlam birliğine sahip oldukları söylenebilir. Bu ortak anlam da özetle şek, tereddüt, zan ve ihtimallerin karar ve hüküm tesisinde dayanak olamayacağı, hükümlerin ancak kesin deliller üzerine bina edilebileceğidir.

\section{Konuyla İlgili Kâidelerin Temeli Olarak Görülebilecek Rivayetler}

Hadis kaynaklarında, söz konusu kâidelere veya bunların ortaya koyduğu temel ilkeye esas teşkil ettiği ${ }^{34}$ düşünülebilecek bazı rivayetler yer almaktadır ki şöyle sıralanabilir:

1) Tayâlisî'nin Müsned'inde Hasan b. Ali'den nakledilen ve genel olarak şüphe ve vehimden uzak durmayı tavsiye eden bir rivayete göre Rasûlullah (s.a) şöyle buyurmuştur: دع ما يريبك إلى ما لا يريبك فإن الصدق طمأنينة وإن الكذب ريبة

“Şüpheli olanı bırak, şüphesiz olana bak! Çünkü doğruluk gönül rahatIığıdır, yalancılık ise kuşkudan ibarettir."35

30 Bkz. Ali Haydar, Dürerü'l-hükkâm, I, 73. Ayrıca bkz. Mesûd Efendi, Mirât-ı Mecelle, s. 32; Yıldırım, Mecelle'nin Küllî Kâideleri, 158.

31 Bkz. Ali Haydar, Dürerü'l-hükkâm, I, 73.

32 Bkz. Mecelle, (mad. 74), s. 32; Ali Haydar, Dürerü'l-hükkâm, I, 73. Ayrıca bkz. Mesûd Efendi, Mir'ât-ı Mecelle, s. 32; Bilmen, Kâmûs, I, 279; Öztürk, Osmanlı Hukuk Tarihinde Mecelle, s. 130.

33 Bkz. Ali Haydar, Dürerü'l-hükkâm, I, 73.

34 Bu temel ilkenin ve aynı zamanda istishâb ilkesinin esası olarak işaret edilen bazı âyetler ve değerlendirmeleri için bkz. Tuzcu, Abdullah, Kur'ân-ı Kerîm Açısından Mecelle'nin Küllî Kaideleri, (Yayımlanmamış Yüksek Lisans Tezi), Atatürk Üniversitesi Sosyal Bilimler Enstitüsü, Erzurum 2012, s. 42-45. 
Bu rivayet Ahmed b. Hanbel'in Müsnedinde de yer almakta olup, "Yahyâ b. Saîd- Şu'be- Büreyd b. Ebû Meryem- Ebû'l-Havrâ es-Sa'dî- Hasan b. Ali." şeklindeki isnâdı Şuayb el-Arnaût tarafından sahîh olarak değerlendimiştir. ${ }^{36}$ Yine Tirmizî de rivayeti Sünen'inde nakletmiş ve hasen sahîh olduğunu belirtmiştir. ${ }^{37}$ Rivayet Hâkim'in el-Müstedrek'inde de nakledilmiş olup yukarıdaki kaynaklarda da bulunan isnâdı ${ }^{38}$ hakkında Zehebî kavî olduğu değerlendirmesinde bulunmuştur. ${ }^{39}$

Bu rivayetin söz konusu kâidelerle ilişkisine Aclûnî de (ö. 1162/1749) dikkat çekmiştir. O, إدفع الشك باليقين "Şüpheyi yakîn ile def et!" şeklindeki, hadis olduğu zannedilen ama aslında hadis olmayıp fakihlerin dillerinde dolaşan fıkıh kâidelerinden biri40 olduğunu belirttiği bir sözü incelerken bu rivayete de yer vermiştir. Aclûnî, bu rivayetin sahîh olduğunu belirttiği gibi kâide için şâhid konumunda olduğunu da ifade etmiştir. ${ }^{41}$

Ancak bu rivayetin muhteva itibariyle daha çok dinî yaşantı hususundaki hassasiyeti teşvik ettiği ve dolayısıyla bireysel yönünün daha baskın olduğu anlaşılmaktadır. Nitekim İbn Hacer de rivayeti değerlendirirken, kişinin şüphe ve tereddüt ettiği şeyleri terk etmesinin takva için büyük bir asıl olduğunu ifade etmiştir. ${ }^{42}$

35 Tayâlisî, Ebû Dâvûd Süleyman b. Dâvûd b. el-Cârûd, Müsned, I-IV, thk. Muhammed b. Abdulmuhsin et-Türkî, Dâru Hicr, Mısır, 1419/1999, II, 499, had. no: 1274. Rivayetin yer aldığı diğer kaynaklar için bkz. Ahmed b. Hanbel, Ebû Abdullah Şeybânî, Müsned, I-L, thk. Şuayb el-Arnaût ve diğerleri, Müessesetü'r-Risâle, Beyrut 1416/1995, III, 249, had. no: 1723; Dârimî, Ebû Muhammed Abdullah Abdurrahman, Sünen, I-II, Çağrı Yay. ve Dâru Sehnûn, İstanbul 1413/1992, Buyû 2, had. no: 2535; Tirmizî, Ebû Îsâ Muhammed b. Îsâ b. Sevre, Câmiu'tTirmizî, Dâru's-Selâm, Riyâd 1999, Sıfatu'l-Kıyâme 60, had. no: 2518; Nesâî, Ebû Abdurrahman Ahmed b. Şuayb b. Ali el-Horâsânî, Sünen, tsh. Ahmed Şemsüddin, Dâru'lKütübi'l-İlmiyye, Beyrut 2009, Eşribe 50, had. no: 5722; Beyhakî, Ebû Bekir Ahmed b. Hüseyin b. Ali b. Mûsâ, es-Sünenü'l-kübrâ, I-X, Meclisü Dâirati'l-Maârifi'n-Nizâmiyye, Haydarâbâd, 1344, V, 335, had. no: 11134; Hâkim, Muhammed b. Abdullah en-Nisâburî, elMüstedrek ale's-Sahîhayn, I-IV, Dâru'I-Kütübi'I-İlmiyye, Beyrut 1411/1990, IV, 110, had. no: 7046.

36 Ahmed, Müsned, III, 249, had. no: 1723.

37 Tirmizî, Sıfatu'l-Kıyâme 60, had. no: 2518.

38 Ancak bu isnâddaki bazı râvî isimlerinde tashif olduğu görülmektedir. Örneğin Büreyd b. Ebû Meryem, Yezîd b. Ebû Meryem olarak, Ebû'l-Havrâ ise Ebû'l-Cevzâ olarak kaydedilmiştir.

39 Hâkim, el-Müstedrek, IV, 110, had. no: 7046.

40 Kâidenin bu şekildeki bir formülasyonu en azından bizim vâkıf olduğumuz kavâid kitaplarında bulunmamakla beraber, özellikle, "Şek ile yakîn zâil olmaz." kâidesinin farklı bir ifadesi olduğu görülmektedir. Yakînin şek üzerindeki tek taraflı etkisini ortaya koymaları açısından da bu iki kâide arasında anlam birliği bulunduğu söylenebilir.

41 Bkz. Aclûnî, İsmâil b. Muhammed, Keşfü'l-hafâ ve muzîlü'l-ilbâs ammâ iştehera mine'l-ehâdîs alâ elsineti'n-nâs, I-II, Dâru İhyâi't-Türâsi'l-Arabî, Beyrut 1352, I, 74.

42 Bkz. İbn Hacer, Şihâbeddin Ahmed b. Ali b. Muhammed b. Ahmed Askalânî, Fethu'l-bârî şerhu Sahîhi'l-Buhârî, I-VIII, Dâru'I-Marife, Beyrut 2005, III, 537. Bu yöndeki diğer yorumlar için bkz. İbn Battâl, Ebu'l-Hasen Ali b. Halef b. Abdülmelik, Şerhu Sahîhi'l-Buhârî, I-X, thk. Ebû Temîm Yâsir b. İbrahim, Mektebetü'r-Rüşd, Riyâd 1423/2003, VI, 196; İbn Receb, 
2) Humeydî'nin Müsned'inde Abdullah b. Zeyd'den nakledilen bir rivayet de şöyledir:

شكي إلى النبي صلى الله عليه وسلم الرجل يخيل إليه الشيء في الصلاة فقال رسول الله صلى الله عليه وسلم: لا ينفتل حتى يسمع صوتا أو يجد ريحا

"Namazda iken kendisinde abdesti bozucu bir durum olduğu (hades çıktığı) $)^{43}$ hissine kapılan kimsenin hali Rasûlullah'a arz edildi. Rasûlullah da, 'Bir ses veya bir koku duymadıkça ${ }^{44}$ namazdan çıkmasın!' buyurdu." ${ }^{45}$

Bu rivayetin mezkûr kaynaktaki isnâdı "Süfyân- Zührî- Saîd b. elMüseyyeb ve Abbâd b. Temîm- Amcası (Abdullah b. Zeyd)." şeklindedir. İbn Hacer bu rivayet ile ilgili değerlendirmesinde rivayetin, Buhârî'nin Sahîh'indeki, "Zührî- Saîd b. el-Müseyyeb- Abbâd b. Temîm." şeklindeki isnâdında yanlışlık olduğunu ifade etmiştir. Buna göre Saîd b. el-Müseyyeb ile Abbâd b. Temîm isimleri arasındaki "gâv" harfi hatâen düştüğü için hadisi öncekinin sonrakinden naklettiği yanılgısı ortaya çıkmıştır. Oysa İbnü'l-Müseyyeb'in Abbâd'dan hiç rivayeti yoktur. Buna binaen isnâdın doğru şekli Zührî'nin hadisi her iki râvîden aldığını göstermektedir. ${ }^{46}$ Nitekim rivayetin Ebû Avâne'nin Müsned'inde bulunan, "Yunus b. Abdulalâ- Süfyân- Zührî- Abbâd b. TemîmAbdullah b. Zeyd." ${ }^{47}$ şeklindeki isnâdının da buna delalet ettiği söylenebilir.

Zeynüddin Ebû'l-Ferec Abdurrahman b. Şihâbüddin el-Hanbelî el-Bağdâdî ed-Dımeşkî, Fethu'I-bârî şerhu Sahîhi'I-Buhârî, I-VI, thk. Ebû Muâz Târık b. Avdullah b. Muhammed, Dâru İbni'l-Cevzî, es-Suûdiyye/Demmâm 1422, I, 206; Aynî, Ebû Muhammed Bedruddin Mahmûd b. Ahmed b. Musa el-Hanefî, Umdetü'l-kârî şerhu Sahîhi'l-Buhârî, I-XXV, tsh. Abdullah Mahmûd Muhammed Ömer, Dâru'l-Kütübi'l-İlmiyye, Beyrut 1421/2001, I, 465; San'ânî, Muhammed b. İsmail el-Emîr el-Kehlânî, Sübülü's-selâm, I-IV, Mektebetü Mustafâ el-Bâbî elHalebî, byy. 1379/1960, IV, 152.

43 Sîrvân, Abdülaziz, et-Tibyân bişerhi mâ't-tefeka aleyhi'ş-şeyhân, I-III, Dâru'r-Reşîd, DımaşkBeyrut 1413/1992, I, 86.

44 Hattâbî bu iki tür hadesin zikredilmesinin, bunlar dışındaki yollarla hadesin oluşmayacağını ima eden bir tahsis ve kasr anlamına gelmediğini sadece sorulan soru dâhilinde verilen bir cevap olduğunu belirtmiştir. Bkz. Aynî, Umdetü'l-kârî, III, 384.

45 Humeydî, Ebû Bekir Abdullah b. Zübeyr b. Îsâ b. Ubeydullah, Müsnedü'l-Humeydî, I-II, thk. Hasan Selîm Esed ed-Dârânî, Dâru's-Sekâ, Dimeşk, 1996, I, 390, had. no: 417. Rivayetin bu versiyonu şu kaynaklarda da kısmen farklı isnâd ve metinlerle yer almaktadır: Ahmed, Müsned, XXVI, 376, had. no: 16450; Buhârî, Muhammed b. İsmail, el-Camiu's-sahîh, Dâru'sSelâm, Riyad 1999, Vudû 4, had. no: 137; Müslim, Ebû'l-Huseyn Müslim b. Haccâc, elCâmiu's-sahîh, I-III, Çağrı Yay. ve Dâru Sehnûn, İstanbul 1413/1992, Hayz 98, had. no: 361; Ebû Dâvûd, Süleyman b. el-Eş'as es-Sicistânî, Sünen, Dâru İbni'l-Cevzî, Kahire 1432/2011, Tahâret 68, had. no: 176. Müslim'in Sahîh'indeki bir rivayet de bu anlamda olmakla beraber lafız yönüyle biraz daha farklıdır. Bkz. Müslim, Hayz 99, had. no: 362. Tirmizî de Sünen'inde bu muhtevada bir rivayete Ebû Hureyre'den naklen yer vererek hasen sahîh olduğu değerlendirmesinde bulunmuş ve konuyla ilgili kendisinden hadis nakledilen sahâbîler olarak da, Abdullah b. Zeyd, Ali b. Talk, Âişe, İbn Abbâs, İbn Mesûd ve Ebû Saîd'in isimlerini zikretmiştir. Bkz. Tirmizî, Tahâret 56, had. no: 75.

46 Bkz. İbn Hacer, Fethu'l-bârî, I, 682. Ayrıca bkz. Özafşar, Mehmet Emin, Hadisi Yeniden Düşünmek, Ankara Okulu Yay., Ankara 2000, s. 149.

47 Ebû Avâne, Ya'kûb b. İshâk el-İsferâinî, Müsnedü Ebî Avâne, I-V, Dâru’l-Ma'rife, Beyrut, trs., I, 2016, had. no: 650 . 
Görüldüğü gibi bu isnâdda hadisi Abbâd b. Temîm'den nakleden kişi Zührî'dir. Yine İbn Mâce'nin Sünen'inde yer alan, Ebû Saîd el-Hudrî'den nakledilen bu muhtevadaki bir rivayetin isnâdına göre de Zührî hadisi Saîd b. elMüseyyeb'den nakletmektedir ki bu da İbn Hacer'in, isnâdın doğru şekli olduğunu belirttiği duruma uygun düşmektedir. Bu isnâd ise şöyledir: "Ebû Küreybel-Muhâribî- Ma'mer b. Râşid- Zührî- Saîd b. el-Müseyyeb- Ebû Saîd elHudrî."48

Ayrıca Rivayetin Müslim'in Sahîh'inde ve İbn Mâce'nin ve Ebû Dâvûd'un Sünen'lerinde bulunan isnâdlarının, yukarıda İbn Hacer'in işaret ettiği, "و/vâv" harfinin düşürülmesi sonucu ortaya çıkan yanlışlıktan uzak olduğu da görülmektedir. Bu isnâdlar ise şöyle sıralanabilir:

Müslim'in isnâdı: "Amr en-Nâkıd, Züheyr b. Harb ve Ebû Bekir b. Ebû Şeybe- Süfyân b. Uyeyne- Zührî- Saîd b. el-Müseyyeb ve Abbâd b. TemîmAmcası (Abdullah b. Zeyd)."49

İbn Mâce'nin isnâdı: "Muhammed b. es-Sabbâh- Süfyân b. UyeyneZührî- Saîd ve Abbâd b. Temîm- Amcası (Abdullah b. Zeyd)."50

Ebû Dâvûd'un isnâdı: "Kuteybe b. Saîd ve Muhammed b. Ahmed b. Ebû Halef- Süfyân- Zührî- Saîd b. el-Müseyyeb ve Abbâd b. Temîm-Amcası (Abdullah b. Zeyd)."51

İbn Hacer daha sonra Saîd b. el-Müseyyeb'in hadisi kimden aldığı konusunu ele alır ve bunda iki ihtimal olduğunu söyler. Birinci ihtimale göre bu Abbâd'ın amcasıdır. Dolayısıyla İbnü'l-Müseyyeb ve Abbâd ikisi beraber hadisi Abbâd'ın amcasından almış olur. İkinci intimale göre ise bu râvî hazf edilmiştir. Bu durumda da hadis İbnü'l-Müseyyeb'in mürsellerinden ${ }^{52}$ sayılır. ${ }^{53}$ Onun mürselleri ise sahîh olarak değerlendirilmektedir. ${ }^{54}$

48 İbn Mâce, Ebû Abdullah Muhammed b. Yezid el-Kazvînî, Sünen, I-II, Çağrı Yay. ve Dâru Sehnûn, İstanbul 1413/1992, Tahâret 74, had. no: 514.

49 Müslim, Hayz 98, had. no: 361.

50 İbn Mâce, Tahâret 74, had. no: 513.

51 Ebû Dâvûd, Tahâret 68, had. no: 176.

52 Mürsel, tâbiînden olan râvînin sahâbî râvîyi atlayarak doğrudan Hz. Peygamber'den naklettiği hadise verilen isimdir.

53 Bkz. İbn Hacer, Fethu'l-bârî, I, 682. Ayrıca bkz. Özafşar, Hadisi Yeniden Düşünmek, s. 149.

54 Mürsel rivayetler içerisinde İbnü'l-Müseyyeb'inkilerin özel bir yeri olduğunu Süyûtî şöyle dile getirir: "Tâbiînin mürselleri içerisinde en sahîh olanlar, Ibn Maîn'in de belirttiği üzere, İbnülMüseyyeb'in mürselleridir. Çünkü o sahâbe çocuklarındandır, aşere-i mübeşşereye kavuşmuştur, Hicâzlıların fakihi ve müftüsüdür, Imam Mâlik'in, icmâlarını bütün insanların icmâsı gibi saydığı yedi fakihin ilkidir, mütekaddim imamlar onun mürsellerini dikkatlice incelemişler ve onların sahîh isnâdlarla geldiklerini görmüşlerdir. Bütün bu şartlar onun dışındakilerin mürsellerinde bulunmamaktadır." Yine Ahmed b. Hanbel'in de, "Mürseller içerisinde en sahîh olanlar Saîd b. el-Müseyyeb'in mürselleridir." dediği nakledilmektedir. 
Mezkûr rivayet Süyûtî ve İbn Nüceym tarafından da bilhassa, "Şek ile yakîn zâil olmaz." kâidesinin esası olarak gösterilmiştir. ${ }^{55}$ Ayrıca Nevevî de rivayetin İslâm dininin esaslarından ve fıkıh kaidelerinin en büyüklerinden biri

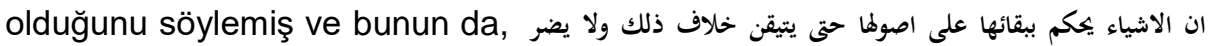
Eşyada asıl olan, aksi kesinleşinceye kadar olduğu hal üzere kalmasıdır. Sonradan ortaya çıkan şüphe ona zarar vermez." kâidesi olduğunu belirtmiştir. ${ }^{56}$ Nevevî'nin işaret ettiği bu kâidenin, "Şek ile yakîn zâil olmaz." kâidesinin biraz daha detaylı ifadesinden ibaret olduğu söylenebilir.

3) Mâlik'in Muvatta'ında Atâ b. Yesâr'dan mürsel olarak nakledilen bir rivayete göre de Hz. Peygamber (a.s) şöyle buyurmuştur:

$$
\begin{aligned}
& \text { إذا شك أحدكم في صلاته فلم يدر كم صلى أثلاثا أم أربعا فليصلي ركعة وليسجد سجدتين وهو جالس قبل التسليم فإن كانت }
\end{aligned}
$$

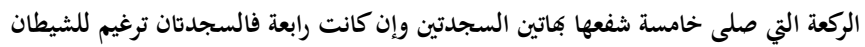

"Sizden biri namaz kılarken tereddüt edip üç mü dört mü kıldığını bilemezse bir rekât daha kılsın ve oturur vaziyette iken selamdan önce iki secde yapsın! Kıldığı rekât beşinci ise bu secdelerle beraber rekâtlar çift olmuş olur. Şayet dördüncü rekâtı kılmışsa bu iki secde şeytanı zelil etmek demektir."57

Mâlik'in mürsel olarak naklettiği bu rivayeti İbn Ebû Şeybe Musannefinde, Ahmed b. Hanbel Müsned'inde ve Müslim Sahîh'inde kısmen farklı lafızlarla Ebû Saîd el-Hudrî'den mevsûl olarak da nakletmişlerdir. ${ }^{58}$ Ayrıca

Bkz. Süyûtî, Celaleddin Abdurrahman, Tedrîbü’r-râvî fî şerhi Takrîbi'n-Nevevî, Dâru İbn Hazm, Beyrut 1430/2009, s. 110.

55 Bkz. Süyûtî, el-Eşbâh ve'n-nezâir, I, 89; İ̉n Nüceym, el-Eşbâh ve'n-nezâir, s. 60. Ayrıca bkz. Bâ Hüseyin, el-Kavâidu'l-fıkhiyye, s. 206; Zuhaylî, el-Kavâidu'l-fıkhiyye, I, 97-98.

56 Bkz. Nevevî, Ebû Zekeriyya Yahya b. Şeref, el-Minhâc şerhu Sahîhi Müslim b. el-Haccâc, IXVIII, Dâru'l-Gaddi'l-Cedîd, Kâhire 1429/2008, IV, 44. Ayrıca bkz. İbn Hacer, Fethu'l-bârî, I, 682; Aynî, Umdetül'-kârî, III, 384.

57 Mâlik b. Enes, Ebû Abdullâh İbn Mâlik b. Ebû Âmir el-Asbahî el-Yemenî, el-Muvatta', I-II, Çağrı Yayınları ve Dâru Sehnûn, İstanbul 1413/1992, Salât 62. Rivayet Abdurrezzak'ın elMusannefinde de yine Atâ b. Yesâr'dan mürsel olarak nakledilmiştir. Bkz. Abdurrezzâk, Ebû Bekr b. Hemmâm es-San'ânî, el-Musannef, I-XI, thk. Habîburrahman el-A'zamî, el-Meclisü'lİlmî, Beyrut 1403/1983, II, 305, had. no: 3466. İbn Abülber, hadisi Mâlik'den nakleden bütün râvîlerin bu şekilde mürsel olarak naklettiklerini belirtmiştir. Bkz. Mâlik, Muvatta', Salât 62 . Ancak İbn Abülber, "el-Velîd b. Müslim- Mâlik- Zeyd b. Eslem- Atâ b. Yesâr- Ebû Saîd elHudrî." şeklindeki mevsûl isnâdın bundan müstesna olduğunu da ifade etmiştir. Bkz. İbn Abdülber, Ebû Amr Yûsuf b. Abdullah en-Nemerî, el-İstizkâr, I-VIII, thk. Sâlim Muhammed Atâ, Muhammed Ali Muavvad, Dâru'l-Kütübi'l-İlmiyye, Beyrut, 1421/2000, I, 513.

58 Bkz. İbn Ebû Şeybe, Ebû Bekir Abdullah b. Muhammed, el-Musannef, I-XXI, thk. Muhammed Avvâme, Dâru'l-Kıble, byy., trs., III, 429, had. no: 4436; Ahmed, Müsned, XVIII, 221-222, had. no: 11689; Müslim, Mesâcid 88, had. no: 571. Bu muhtevadaki mufassal ve muhtasar diğer rivayetler için bkz. İbn Mâce, İkâmetü's-Salât 132, had. no: 1210; Ebû Dâvûd, Salât 197, had. no: 1024, 1026, 1027, 198, had. no: 1028, 1029, 1030; Tirmizî, Salât 174, had. no: 396, 397, 398. Yine konuyla ilgili ancak tereddüt halinde yapılması gereken şeyi farklı bir yönden ele alan bir rivayet de Ahmed b. Hanbel'in Müsned'inde Abdurrahman b. Avf'tan nakledilmektedir

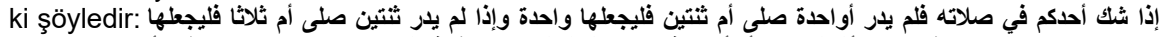
"Sizden biri namazında tereddüt eder de bir rekât mı iki rekât mı kıldığını bilemezse kıldığını bir rekât 
rivayetin Müsned'deki versiyonunu Şuayb el-Arnaût sahîh olarak değerlendirmiştir ki ${ }^{59}$ yine Muvatta'daki gibi Zeyd b. Eslem'in Atâ b. Yesâr'dan nakli suretiyledir.

Yine ibadet sahasından olan bu rivayet özetle namazın rekâtlarında şüpheye düşüldüğünde yapılması gereken şeyleri bildirmektedir. İbn Abdülber rivayetin değerlendirmesini yaparken bunun, birçok hükmü kapsayan büyük ve önemli bir fıkhî asla kaynak teşkil ettiğini belirtmiş ${ }^{60}$, bu fıkhî aslı da şöyle ifade etmiştir: أن اليقين لا يزيله الشك وأن الشيء مبني على أصله المعروف حتى يزيله يقين لا شك معال "Muhakkak ki yakîn, şüphe tarafından ortadan kaldırılamaz. Ve bir şey, beraberinde şüphe olmayan yakîn kendisini ortadan kaldırıncaya kadar, bilinen aslı üzere sabit kalır."61 Bu fıkhî aslın da yukarıda Nevevî'den nakledilen kâidede olduğu gibi, "Şek ile yakîn zâil olmaz." kâidesinin detaylı ve kapsamlı bir ifadesi olduğu söylenebilir. Ayrıca Süyûtî de yukarıdaki rivayetle aynı muhtevadaki bazı rivayetlere kâidenin esası olarak işaret etmiştir. ${ }^{62}$

İbn Nüceym ise, her ne kadar konuyla ilgili bu rivayetlerden bahsetmese de uygulamaya teorik olarak işaret etmiştir. ${ }^{63}$ Ancak onun bu uygulama ile örneklendirdiği kâideler, mevzu bahis olan kâidelerle bir noktada anlam birliğine sahip olsalar da farklı şekillerde formüle edilmişlerdir ki bunlar, من شك فك "Bir kimse bir şeyi yapıp yapmadığından şüphelense

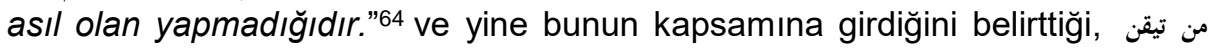
Bir kimse bir şeyi yaptığını kesin olarak bilse ancak az veya çok yaptığında şüphe etse az yaptığı varsayılır. Çünkü azda şüphe yoktur."65 kâideleridir. Bu kâidelere Süyûtî de küçük lafız farklarıyla beraber yer vermiştir. ${ }^{66}$ Ancak ifade edilmelidir ki bu müelliflerden daha

saysın! Iki rekât mı üç rekât mı kıldığını bilemezse kıldığını iki rekât saysın! Üç rekât mı dört rekât mı kıldığını bilemezse kıldığını üç rekât saysın! Namazını bitirdiğinde de selâm vermeden önce oturur haldeyken iki defa secde etsin!' Bkz. Ahmed, Müsned, III, 195, had. no: 1656. Rivayet şu kaynaklarda da yer almaktadır: İbn Mâce, İkâmetü's-Salât 132, had. no: 1209; Hâkim, el-Müstedrek, I, 471, had. no: 1213. Ayrıca rivayetin muhtasar bir versiyonu için bkz. İbn Ebû Şeybe, el-Musannef, III, 432, had. no: 4447. Bu son zikredilen kaynaklarda حتى "Tâ ki yanılgı fazla kılmakta olsun." şeklinde bir açıklama cümlesi de bulunmaktadır.

59 Ahmed, Müsned, XVIII, 222, had. no: 11689.

60 İbn Abdülber, el-İstizkâr, I, 513-514.

61 İbn Abdülber, el-İstizkâr, I, 514.

62 Bkz. Süyûtî, el-Eşbâh ve'n-nezâir, I, 89-90. Ayrıca bkz. Zuhaylî, el-Kavâidu'l-fıkhiyye, I, 98.

63 Bkz. İbn Nüceym, el-Eşbâh ve'n-nezâir, s. 64.

64 İbn Nüceym, el-Eşbâh ve'n-nezâir, s. 64. Ayrıca bkz. Hâdimî, Mecâmi', s. 371.

65 İbn Nüceym, el-Eşbâh ve'n-nezâir, s. 64.

66 Bkz. Süyûtî, el-Eşbâh ve'n-nezâir, I, 97. 
önce Şâfiî fakih İbnu'l-Kâss da benzer ifadelerle bilhassa ilk kâideden bahsetmiştir. ${ }^{67}$

Lafzî açıklık itibariyle mezkûr rivayetin bilhassa bu son zikredilen kâidelere doğrudan esas teşkil ettiği söylenebilir. Nitekim burada şüphe, zan, vehim gibi kesinlikten uzak durumların karara mesned teşkil edemeyeceği ve sadece yakinen bilinen şeyler üzerine hüküm tesisinin mümkün olduğu ortaya konulmuştur.

4) İbn Ebû Şeybe'nin Hz. Âişe'den naklettiği bir rivayete göre de Rasûlullah (a.s) şöyle buyurmuştur:

ادرؤوا الحدود عن المسلمين ما استطعتم فإذا وجدتم للمسلم مخرجا فخلوا سبيله فإن الإمام أن يخطى في العفو خير من أن يخطئ في العقوبة

“Müslümanlardan gücünüz yettiğince cezaları kaldırın! Müslüman için bir çıkış yolu bulduğunuzda önünü açıverin! (cezadan kurtarın!). Hâkimin affetmekte yanılması ceza da yanılmasından daha hayırlıdır."68

Tirmizî, bu mevzu ile ilgili Ebû Hureyre ve Abdullah b. Amr'dan da hadis rivâyet edildiğini belirttikten sonra Hz. Âişe'den nakledilen mezkûr rivayetin merfû olarak sadece, "Muhammed b. Rabîa- Yezîd b. Ziyâd ed-DımeşkîZührî- Urve- Âişe” isnâdıyla geldiğinin bilindiğini söylemiş ayrıca Vekî'in Yezîd b. Ziyâd'dan hadisin bir benzerini rivayet ettiğini ancak ref' etmediğini ve daha sahîh olanın da bu Vekî rivayeti olduğunu ifade etmiştir. Tirmizî bunlara, Rasûlullah'ın (s.a) ashâbından pek çok kişiden bunun benzerinin rivâyet edil-

67 İbnü'l-Kâss, Ebû'l-Abbâs Ahmed b. Ebû Ahmed et-Taberî, et-Telhîs, thk. Âdil Ahmed Abdulmevcûd, Ali Muhammed Muavvad, Mektebetü Nizâr Mustafâ el-Bâz, byy., trs., s. 121. Ayrıca bkz. Bâ Hüseyin, el-Kavâidu'l-fıkhiyye, s. 309.

68 İbn Ebû Şeybe, el-Musannef, XIV, 455, had. no: 29094. Rivayetin yer aldığı diğer kaynaklar için bkz. Tirmizî, Hudûd 2, had. no: 1424; Dârekutnî, Ali b. Ömer, Sünen, I-V, thk. Şuayb elArnaût, Hasen Abdülmün'im Şelebî, Abdullatif Hırzallah, Ahmed Berhûm, Müessesetü'rRisâle, Beyrut 1424/2004, IV, 62-63, had. no: 3097, 3098; Hâkim, el-Müstedrek, IV, 426, had. no: 8163; Beyhakî, es-Sünenü'l-kübrâ, VIII, 238, had. no: 17513; Tânevî, Zafer Ahmed elOsmânî, I'lâu's-sünen, I-XXI, Dâru'l-Fikr, Beyrut 1421/2001, IX, 4306, had. no: 3587; Aclûnî, Keşfüll-hafâ, I, 73. Tîbî bu rivayet ile تعافوا الحدود فيما بينكم فما بلغني من حد فقل وجب "Birbirinizi affederek had cezası gerektiren davaları kendi aranızda sonlandırın! Had cezası gerektiren bir dava bana ulaştığı zaman cezayı tatbik etmek vacip olur." (Ebû Dâvûd, Hudûd 5, had. no: 4376) şeklindeki merfû rivayetin anlam cihetiyle örtüştüğünü belirtmiştir. Bkz. Mubârekfûrî, Ebû'l-Ullâ Muhammed Abdurrahman b. Abdurrahim, Tuhfetü'l-ahvezî bi şerhi Câmii't-Tirmizî, I-X, tsh. Abdurrahman Muhammed Osman, Dâru'I-Fikr, Beyrut trs., IV, 688. Muhakeme usûlü ile ilgili olup özetle farklı intimaller söz konusu olduğunda cezaların infaz edilmemesi gerektiğini ortaya koyan bu rivayete Süyûtî ve İbn Nüceym de الحدود تسقط بالثبهات "Şüphelerle hadler düşürülür." şeklinde formüle ettikleri bir kâidenin esası olarak işaret etmişlerdir. Bkz. Süyûtî, el-Eşbâh ve'n-nezâir, I, 203-204; İbn Nüceym, el-Eşbâh ve'n-nezâir, s. 142. (İbn Nüceym, تدراً kelimesine yer vermiştir). Ancak Süyûtî şüphenin güçlü şüphe olması gerektiğine, aksi takdirde etkisi olmayacağına da dikkat çekmiştir. Bkz. Süyûtî, el-Eşbâh ve'nnezâir, I, 206. 
diği ve onların da bunun aynısını söyledikleri bilgisini de eklemiştir. ${ }^{69}$ Ancak hadisin râvîlerinden Yezîd b. Ziyâd ed-Dımeşkî'nin hadiste zayıf olduğu da yine Tirmizî tarafından belirtilmiştir. ${ }^{70}$ Hatta bu râvî ile ilgili Ebû Hâtim, Buhârî ve Nesâî gibi âlimler tarafından münkeru'l-hadis, metrûkü'l-hadis ve zâhibu'l-hadis (hadisleri kesinlikle yazılmaz, terk edilir) olduğu yönünde hükümler de verilmiş ve yine hadislerinin mevzû olmaya yakın bulunduğu Ebû Hâtim tarafından bir başka zamanda ifade edilmiştir. ${ }^{71}$ Dolayısıyla bu bilgiler ışığında hadisin zayıf olduğunu söylemek mümkündür. Bununla beraber Hâkim elMüstedrek'inde bu hadisi, "el-Kâsım b. el-Kâsım es-Seyyârî- Ebû'l-MüveccehAbdân- el-Fadl b. Musa- Yezîd b. Ziyâd el-Eşcaî- Zührî- Urve- Âişe." şeklindeki bir isnâd ile rivayet etmiş ve bu isnâdın sahîh olduğunu ancak Buhârî ve Müslim tarafından tahric edilmediğini belirtmiştir. ${ }^{72}$ Zehebî de Hâkim'i takiben râvîlerden Yezîd b. Ziyâd eş-Şâmî hakkında Nesaî'nin metrûk dediğini ifade etmiştir. ${ }^{73}$ Ancak dikkat edilmelidir ki Hâkim'in kaydettiği isnâdda bulunan râvî, Yezîd b. Ziyâd eş-Şâmî değil, Yezîd b. Ziyâd el-Eşcaî'dir. Bu râvî hakkında verilen hükümler ise olumludur. Örneğin Ahmed b. Hanbel, İbn Maîn ve İclî sika olduğunu söylemişlerdir. Ebû Zür'a şeyh olduğunu, Ebû Hâtim ve Nesâî hadisinde sorun olmadığını, yine Nesâî sâlihu'l-hadis olduğunu belirtmiş, İbn Hibbân Sikât'ında zikretmiş̧ ${ }^{74}$, İbn Hacer de Takrîb'de sadûk olduğu notunu düşmüştür. ${ }^{75}$

Dârekutnî ve Beyhakî de Sünen'lerinde hadisi, Tirmizînnin Sünen'indeki metinle, bazı lafız ve takdim-tehir farkları dışında hemen hemen aynı ve Hz. Âişe'den merfû olarak rivayet etmişlerdir. ${ }^{76}$ Ancak Beyhakî, yukarıda Tirmizî'den de nakledildiği üzere, Vekî rivayetinin yani hadisin $\mathrm{Hz}$. Âişe'den mevkûf olarak nakledilmesinin doğruya daha yakın olduğunu da ifade etmiş-

Tirmizî, Hudûd 2, had. no: 1424. Ayrıca bkz. Zeylaî, Abdullah b. Yûsuf, Nasbu'r-râye liehâdîsi'l-Hidâye, I-V, thk. Muhammed Avâme, Müessesetü'r-Reyyân, Cidde 1418/1997, III, 309, had. no: 5405; Tânevî, l'lâu's-sünen, IX, 4310.

70 Tirmizî, Hudûd 2, had. no: 1424. Ayrıca bkz. Mizzî, Cemalüddin Ebû Haccac Yusuf, Tehzîbu'l-Kemâl fî esmâi'r-ricâl, I-XXXV, thk. Beşşâr Avvâd Marûf, Müessesetü'r-Risâle, Beyrut 1403/1983, XXXII, 135; Zeylaî, Nasbu'r-râye, III, 309, had. no: 5405; İbn Hacer, Şihâbeddin Ahmed b. Ali b. Muhammed b. Ahmed el-Askalânî, Tehzîbu't-Tehzîb, I-IV, Müessesetü'r-Risâle, Beyrut 1995, IV, 413.

71 Bkz. Mizzî, Tehzîbu'l-kemâl, XXXII, 134-135. Ayrıca bkz. Zeylaî, Nasbu'r-râye, III, 309, had. no: 5405; İbn Hacer, Tehzîbu't-Tehzîb, IV, 413; a.mlf., Takrîbu't-Tehzîb, I-II, Dâru'I-Kütübi'lİlmiyye, Beyrut 1415/1995, II, 324.

72 Hâkim, el-Müstedrek, IV, 426, had. no: 8163.

73 Hâkim, el-Müstedrek, IV, 426, had. no: 8163. Ayrıca bkz. Zeylaî, Nasbu'r-râye, III, 309, had. no: 5405; İbn Hacer, Takrîbu't-Tehzîb, II, 324.

74 Bkz. Mizzî, Tehzîbu’l-kemâl, XXXII, 131. Ayrıca bkz. İbn Hacer, Tehzîbu't-Tehzîb, IV, 412.

75 Bkz. İbn Hacer, Takrîbu't-Tehzîb, II, 324.

76 Dârekutnî, Sünen, IV, s. 62-63, had. no: 3097, 3098; Beyhakî, es-Sünenü'l-kübrâ, IX, 123, had. no: 18757. Ayrıca bkz. Zeylaî, Nasbu'r-râye, III, 309, had. no: 5405. 
tir. ${ }^{77}$ Yine Beyhakî, Rişdîn b. Sa'd'ın Ukayl'den onun da Zührî'den naklettiği merfû bir isnâdın daha olduğunu, ancak Rişdîn'in zayıf olduğunu da belirtmiştir. ${ }^{78}$

Muasır âlimlerden Elbânî ise hadisin merfû ve mevkûf olmak üzere her iki halde de zayıf olduğunu belirtmiştir. Çünkü onun ifadesiyle hadis her halükarda Yezîd b. Ziyâd ed-Dımeşkî̀ye dayanmaktadır. Bu ise Takrîb'de de yer aldığı üzere metrûk bir râvîdir. ${ }^{79}$ Yine Elbânî Zehebî'nin, bu râvînin metrûk olduğu yönündeki, Nesâî'nin yukarıda da işaret edilen görüşünü nakletmesinin, Hâkim'in rivayetin sahîh olduğuna dair hükmünü reddettiği anlamına geldiğini de belirtmiştir. ${ }^{80}$ Ancak yukarıda da belirtildiği üzere Hâkim'in İsnâdında bulunan râvî Nesâî'nin bahsettiği râvî değil, sika ve sadûk bir râvî olduğu belirtilen ${ }^{81}$ Yezîd b. Ziyâd el-Eşcaî'dir. Dolayısıyla Hâkim'in, rivayetin sahîh olduğu yönündeki değerlendirmesinin yerinde olduğu söylenebilir.

Ayrıca Beyhakî, rivayetin sadece, ادرووا الحدود "Hadleri düşürün!" kısmından oluşan oldukça muhtasar bir versiyonunu $\mathrm{Hz}$. Ali'den de merfû olarak nakletmiştir. ${ }^{82}$ Ancak yine o, bu rivayetin, "Ebû Bekir b. el-Hâris el-EsbahânîAli b. Ömer- Muhammed b. el-Kâsım b. Zekeriyyâ- Ebû Küreyb- Muâviye b. Hişâm- Muhtâr et-Temmâr- Ebû Matar- Ali." şeklindeki isnâdının zayıf olduğunu da belirtmiştir. ${ }^{83}$ Elbânî ise bu rivayetin illetinin, zayıf bir râvî olması nedeni ile Muhtâr et-Temmâr olduğunu ifade etmiştir. ${ }^{84} \mathrm{Bu}$ râvînin asıl adı Muhtâr b. Nâfi'dir ki hakkında Buhârî de münkerü'l-hadîs değerlendirmesinde bulunmuştur. ${ }^{85}$ Nesâî, Ebû Hâtim ve Sâcî gibi âlimlerin bu râvî hakkındaki yargıları da yine münkerü'l-hadîs olduğu yönünde olmakla beraber Nesâî bir başka yerde sika olmadığını söylemiştir. ${ }^{86}$ Ancak bu râvînin İclî tarafından sika olarak değerlendirilmesi ${ }^{87}$, rivayetin sıhhatinin en azından tartışmalı olduğunu söylemeyi mümkün kılmaktadır.

77 Bkz. Beyhakî, es-Sünenül-kübrâ, VIII, 238, had. no: 17514. Ayrıca bkz. Zeylaî, Nasbu’r-râye, III, 309, had. no: 5405.

78 Bkz. Beyhakî, es-Sünenü'l-kübrâ, VIII, 238, had. no: 17514.

79 Bkz. Elbânî, Muhammed Nâsıruddin, İvâu'l-ğalîl fî tahrîci ehâdîsi Menâri's-sebîl, I-VIII, Mektebu'l-İslâmî, Beyrut 1405/1985, VIII, 29.

80 Bkz. Elbânî, İvâu'l-ğalîl, VIII, 29.

81 Bkz. İbn Hacer, Tehzîbu't-Tehzîb, IV, 412; a.mlf., Takrîbu't-Tehzîb, II, 324.

82 Bkz. Beyhakî, es-Sünenü'l-kübrâ, VIII, 238, had. no: 17515. Ayrıca bkz. Süyûtî, el-Eşbâh ve'n-nezâir, I, 204.

83 Bkz. Beyhakî, es-Sünenü'l-kübrâ, VIII, 238, had. no: 17515.

84 Bkz. Elbânî, Irvâu'l-ğalîl, VIII, 29. İbn Hacer de bu râvî hakkında zayıf olduğu notunu düşmüştür. Bkz. İbn Hacer, Takrîbu't-Tehzîb, II, 165.

85 Bkz. Beyhakî, es-Sünenü'l-kübrâ, VIII, 238, had. no: 17516. Ayrıca bkz. İbn Hacer, Tehzîbu'tTehzîb, IV, 39; Elbânî, İrvâu'l-ğalîl, VIII, 29.

86 Bkz. İbn Hacer, Tehzîbu't-Tehzîb, IV, 39.

87 Bkz. İbn Hacer, Tehzîbu't-Tehzîb, IV, 39. 
Konuyla ilgili bir başka merfû rivayet de İbn Mâce'nin Sünen'inde Ebû Hureyre'den nakledilmektedir. Bu rivayete göre de Hz. Peygamber (a.s): ادفعوا "Düşürmek için bir gerekçe bulduğunuz sürece hadleri düşürünüz!" 88 buyurmuştur. Ancak bu hadisin senedindeki İbrahim b. el-Fadl elMahzûmî'nin, Ahmed b. Hanbel, İbn Maîn, Ebû Zür'a, Ebû Hâtim, Buhârî, Tirmizî, Nesaî, Dârekutnî ve diğer bazı muhaddisler tarafından daîfu'l-hadis, münkeru'l-hadis, metrûk gibi cerh lafızlarıyla nitelendirildiği ve yine sika olmayıp hadisinin yazılamayacağı hükmünün verildiği de ifade edilmelidir. ${ }^{89}$ Bu nedenle rivayetin sıhhat vasfını kazanamadığını söylemek mümkündür.

Yukarıda zikredilen hadislerde yer alan "gücünüz yettiğince" ve "bir gerekçe bulduğunuz sürece" ifadeleri nispeten kapalı ifadelerdir. Bunların anlamlarını daha belirgin şekilde ortaya koyan bir rivayette hadlerin düşürülmesinin bir gerekçesi olarak "şüphe" kavramına yer verilmiştir. Bu rivayete göre Hz. Peygamber (a.s): إدرئوا الحدود بالشبهات "Hadleri şüphelerle düşürünüz!"90 buyurmuştur. Zeylaî hadisin bu lafızlarla garîb olduğunu belirtmektedir. ${ }^{91}$ İbn Hacer de rivayetin farklı lafızlarla gelen ve yukarıda da değinilen bazı versiyonları hakkında bilgi verdikten sonra ${ }^{92}$ söz konusu metni merfû' olarak bulamadığını belirtmiş ve konuyla ilgili, aşağıda da geleceği üzere bir kısım sahâbî ve tâbiî sözlerine yer vermiştir. ${ }^{93}$ Ayrıca rivayetin İbn Abbâs, Hz. Ali ve Hz. Âişe'den hasen olarak nakledildiği de söylenmiştir. ${ }^{94}$ İbn Nüceym de rivayetin bu metnine doğrudan yer vermemekle beraber yukarıda da işaret edilen, "Şüphelerle hadler düşürülür."95 şeklinde formüle ettiği bir fıkıh kâidesini bu rivayetten aldığını tahmin etmek zor değildir.

Yukarıda da değinildiği üzere konu ile ilgili bazı mevkûf rivayetler de bulunmaktadır. Örneğin Abdurrezzak'ın Musannefinde İbn Mesûd'dan nakledilen bir rivayet şöyledir: إدرئوا الحدود والقتل عن عبادالله ما استطعتم "Allah'ın kullarından, hadleri ve idam cezasını gücünüz yettiği kadar kaldırın!"96 Bu rivayet Taberânî'nin el-Mu'cemu'l-kebîr'inde de yine İbn Mesûd'un sözü olarak ve yine aynı metinle

88 İbn Mâce, Hudûd 5, had. no: 2545. Ayrıca bkz. İbn Hacer, Şihâbeddin Ahmed b. Ali b. Muhammed b. Ahmed el-Askalânî, ed-Dirâye fî tahrîci ehâdîsi'l-Hidâye, I-II, thk. Seyyid Abdullah Hâşim el-Yemânî el-Medenî, Dâru'l-Ma'rife, Beyrut, trs., II, 95, had. no: 640; Aclûnî, Keşfu'I-hafâ, I, 74; Tânevî, l'lâu's-sünen, IX, 4308, had. no: 3590.

89 Bkz. İbn Hacer, Tehzîbu't-Tehzîb, I, s. 79-80. Ayrıca bkz. Aynî, Umdetü'l-kârî, XX, 369.

90 Ebû Hanîfe, Nu'mân b. Sâbit, Müsnedü Ebû Hanîfe, thk. Ebû Muhammed el-Asyûtî, Dâru'lKütübi'l-IIlmiyye, Beyrut 2008, s. 39, had. no: 70; Zeylaî, Nasbu'r-râye, III, 333, had. no: 5519; Aclûnî, Keşfu'l-hafâ, I, 73, had. no: 166; Tânevî, I'lâu's-sünen, IX, 4307, had. no: 3588.

91 Zeylaî, Nasbu'r-râye, III, 333, had. no: 5519.

92 İbn Hacer, ed-Dirâye fî tahrîci ehâdîsi'l-Hidâye, II, 94-95, had. no: 640.

93 İbn Hacer, ed-Dirâye fî tahrîci ehâdîsi'l-Hidâye, II, 101, had. no: 665.

94 Tânevî, l'lâu's-sünen, IX, 4311.

95 İbn Nüceym, el-Eşbâh ve'n-nezâir, s. 142.

96 Abdurrezzak, el-Musannef, VII, 402, had. no: 13640.

ÇÜiFD, 2018, cilt: 18, sayı: 1, ss. 361-389 
yer almaktadır. ${ }^{97}$ Rivayetin Beyhakînnin Sünen'indeki metni ise bazı lafız farklarına sahiptir ki şöyledir: ادروا الجلد والقتل عن المسلمين ما استطعتم "Müs/ümanlardan celd (sopa) ve idam cezasını gücünüz yettiği kadar kaldırın!" 98 İbn Mesûd'dan mevkûf olarak nakledilen bu rivayetin Beyhakî'nin Sünen'indeki başka bir metni ise bundan farklı olup, bazı takdim-tehir ve lafız farkları dışında $\mathrm{Hz}$. Âişe'den merfû olarak nakledilen metne benzemektedir. ${ }^{99}$ Yine Hz. Ömer'in de, لأن أعطل الحدود بالشبهات أحب إلي من أن أقيمها بالشبهات "Şüpheler nedeni ile hadleri iptal etmek, şüphelere rağmen onları uygulamaktan çok daha fazla hoşuma gider."100 dediği nakledilmektedir. Muâz b. Cebel, Abdullah b. Mes'ûd ve Ukbe b. Âmir'in ise, إذا اشتبه عليك الحد فادرأه "Had cezasını uygulamakta şüpheye düşersen cezayı iptal et?"101 dedikleri rivayet edilmiştir. Tâbiîn âlimlerinden İbn Şihâb ezZührî’den de, ادفعوا الحدود لكل شبهة "Her türlü şüpheyi gerekçe sayarak hadleri iptal edin!'102 şeklinde bir söz nakledilmektedir.

Hadlerin şüphe gerekçesi ile iptal edilmesi doğrultusundaki bu rivayetlerin sıhhati ve Hz. Peygamber'e (a.s) isnadı hususunda farklı bazı yorum$\operatorname{lar}^{103}$ olsa da bu ilkenin gerek Hz. Peygamber (a.s) döneminde gerekse sonraki dönemlerde genel kabul gördüğü ve pratik olarak da kendisine yer bulduğu anlaşılmaktadır. Nitekim İbn Nüceym de, Fethu'l-kadîr'den naklen büyük şehirlerin fakihlerinin, şüphe gerekçesi ile had cezalarının düşürülmesi konusunda icmâ ettiklerini ve yine bu konuda nakledilen hadisin müttefekun aleyh olup ümmetin bunu kabul ile karşıladığını belirtmiştir. ${ }^{104}$

5) Tayâlisî'nin Müsned'inde İbn Abbâs'tan nakledilen bir rivayet de Hz. Peygamber'in (a.s) yukarıda kaydedilen kavlî sünnetinin fiilî olarak da uygulandığını göstermektedir. Buna göre özetle Hilâl b. Ümeyye, Hz. Pey-

97 Bkz. Taberânî, Ebû'l-Kâsım Süleyman b. Ahmed, el-Mu'cemu'l-kebîr, I-XX, thk. Hamdî b. Abdülmecîd Selefî, Mektebetü'l-Ulûm ve'l-Hikem, Musul 1404/1983, IX, 341, had. no: 9716. Süyûtî ve İbn Nüceym de el-Eşbâh ve'n-nezâirlerinde bu rivayete temas etmişlerdir. Bkz. Süyûtî, el-Eşbâh ve'n-nezâir, I, 205; İbn Nüceym, el-Eşbâh ve'n-nezâir, s. 142.

98 Beyhakî, es-Sünenül-kübrâ, VIII, 238, had. no: 17520.

99 Bkz. Beyhakî, es-Sünenü'l-kübrâ, VIII, 238, had. no: 17518.

100 İbn Ebû Şeybe, el-Musannef, IX, 359, had. no: 28963. Ayrıca bkz. İbn Abdülber, el-istizkâr, VIII, 13; Zeylaî, Nasbu'r-râye, III, 333, had. no: 5520; İbn Hacer, ed-Dirâye fî tahrîci ehâdîsi'lHidâye, II, 101, had. no: 665; Aclûnî, Keşfu'l-hafâ, I, 74.

101 İbn Ebû Şeybe, el-Musannef, IX, 359, had. no: 28964; Ayrıca bkz. Dârekutnî, Sünen, IV, 64, had. no: 3099; Beyhakî, es-Sünenü'l-kübrâ, VIII, 238, had. no: 17519; Zeylaî, Nasbu'r-râye, III, 333, had. no: 5521; İbn Hacer, ed-Dirâye fî tahrîci ehâdîsi'l-Hidâye, II, 101, had. no: 665; Tânevî, i'lâu's-sünen, IX, 4310.

102 İbn Ebû Şeybe, el-Musannef, IX, 360, had. no: 28967; Ayrıca bkz. Zeylaî, Nasbu'r-râye, III, 333, had. no: 5522; İbn Hacer, ed-Dirâye fî tahrîci ehâdîsi'I-Hidâye, II, 101, had. no: 665.

103 Bu doğrultudaki rivayetlerin genel bir değerlendirmesi için bkz. Aclûnî, Keşfu'l-hafâ, I, 73-74.

104 Bkz. İbn Nüceym, el-Eşbâh ve'n-nezâir, s. 142. 
gamber'in (a.s) huzurunda karısının bir adamla ${ }^{105}$ zina yaptığı iddiasında bulunur. Hz. Peygamber de kendisinden bunu kanıtlamasını ister. Ancak Hilâl iddiasını kanıtlayamaz. Bunun üzerine mülâane âyeti ${ }^{106}$ iner ve taraflar bu âyet gereğince mülâanede bulunur. Rivayetin konuyla ilgili bundan sonraki kısmı şöyledir:

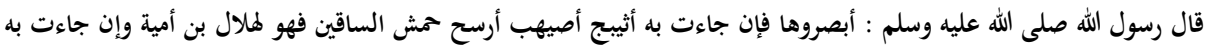

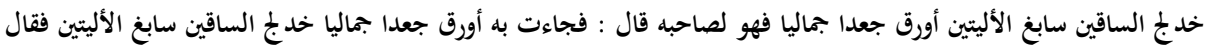

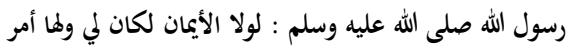

"Rasûlullah (a.s), 'Bu kadına bakınız! Eğer kadın az kambur, kızıl renkli, kalçalarının eti az, ince bacaklı bir çocuk dünyaya getirirse bu çocuk Hilâl b. Ümeyye'nindir. Eğer bacakları kalın, kalçası geniş, esmer, kıvırcık saçlı, iri yapılı bir çocuk dünyaya getirirse bu çocuk sahibinindir (zina isnad edilen şahsındır).' dedi. Gerçekten kadın esmer, kıvırcık saçlı, iri yapılı, kalın bacaklı, geniş kalçalı bir çocuk doğurdu. Bunun üzerine Rasûlullah (a.s): 'Eğer yeminler olmasaydı benim bu kadın için elbette bir muamelem olurdu (yani bu kadına zina cezası uygulardım).' dedi."107

Tirmizî bu rivayeti, "Bündâr (Muhammed b. Beşşâr)- Muhammed b. Ebû Adiy- Hişâm b. Hassân- Ikrime- İbn Abbâs." isnâdıyla nakletmiş ve Hişâm b. Hassân hadisi olarak bu isnâd ile hasen garîb olduğunu belirtmiştir. Yine onun ifadesiyle Abbâd b. Mansûr bu hadisi İkrime'den, o İbn Abbâs'dan o da $\mathrm{Hz}$. Peygamber'den yine bu şekilde rivayet etmiştir ki bu aynı zamanda yukarıda kaydedilen metnin de isnâdıdır. ${ }^{108}$ Eyyûb ise İkrime'den mürsel olarak rivâyet etmiş ve senedinde İbn Abbâs'ın adını zikretmemiştir. ${ }^{109}$ Hatîb el-

105 Rivayetin yer aldığı, aşağıda da zikredilen kaynakların bazılarında bu adamın isminin Şerîk b. Sehmâ olduğu kayıtlıdır.

106 Nûr, 24/6-9.

107 Tayâlisî, Müsned, IV, 388, had. no: 2789. Rivayet hem muhtasar hem de mufassal olarak şu kaynaklarda da yer almaktadır: Ahmed, Müsned, IV, 33-36, had. no: 2131, XIX, 435, had. no: 12450; Abd b. Humeyd, Ebû Muhammed el-Kissî, Müsned, thk. Subhî Bedrî Sâmerrâî, Mahmûd Muhammed Halîl Saîdî, Mektebetü's-Sünne, Kahire 1408/1988, I, 366, had. no: 1218; Buhârî, Tefsîr, Nûr Sûresi (24) 3, had. no: 4747; Müslim, Liân 11, had. no: 1496; İbn Mâce, Talâk 27, had. no: 2067; Ebû Dâvûd, Talâk 27, had. no: 2254; Tirmizî, Tefsîr 24, had. no: 3179; Nesâî, Talâk 38, had. no: 3466; Bezzâr, Ebû Bekir Ahmed b. Amr b. Abdulhâlık elAtekî, Müsnedü'l-Bezzâr (Bahru'z-zehhâr), I-XVIII, thk. Mahfûzurrahman Zeynullah, Âdil b. Sa'd, Sabrî Abdulhâlık eş-Şâfiî, Mektebetü'l-Ulûm ve'l-Hikem, Medîne, 1988-2009, XIII, 233, had. no: 6727; Ebû Ya'lâ, Ahmed b. Ali b. el-Müsennâ el-Mûsulî, Müsnedü Ebû Ya'lâ, I-XIII, thk. Hüseyin Selîm Esed, Dâru'l-Me'mûn li't-Turâs, Dımeşk 1404/1984, V, 209, had. no: 2825; Ebû Avâne, Müsned, III, 209, had. no: 4705; Dârekutnî, Sünen, IV, 419, had. no: 3712.

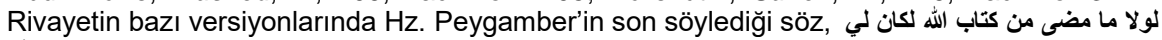
"Eğer Allah’ın Kitâbı'nda lanetleşme hükmü geçmemiş olsaydı benim bu kadın için elbette bir muamelem olurdu (yani ben bu kadına zina cezası uygulardım)." şeklindedir.

108 Şuayb el-Arnaût rivayetin Ahmed b. Hanbel'in Müsnedindeki bahsedilen isnâda sahip versiyonunu hasen olarak değerlendirmiştir. Bkz. Ahmed, Müsned, IV, 36, had. no: 2131.

109 Bkz. Tirmizî, Tefsîr 24, had. no: 3179. 
Bağdâdî ise söz konusu isnâdı sahîh olarak değerlendirmiştir. ${ }^{110}$ Muasır âlimlerden Elbânî de Ebû Dâvûd'un Sünen'indeki Hişâm b. Hassân rivayeti hakkında yine sahîh olduğu değerlendirmesinde bulunmuştur. ${ }^{111}$ Ayrıca Müslim'in Sahîh'inde ve Nesâî'nin Sünen'inde rivayeti Muhammed b. Sîrîn Enes b. Mâlik'den naklederken, Kütüb-i sitte'nin diğerlerinde İkrime, İ̉n Abbâs'dan nakletmektedir.

Rivayette görüldüğü üzere Hz. Peygamber (a.s) Kur'ân-ı Kerim'de, mülâanede bulunanlara had cezasının uygulanmaması yönünde açık bir hüküm varken, kendi tahmin ve çıkarımlarına dayalı bir hükmü uygulamamıştır. Bu da Nevevî'nin de ifadesiyle hükümlerin, özellikle de had cezalarının karineler ve varsayımlar üzerine değil katî deliller üzerine bina edilmesi gerektiğini göstermektedir. ${ }^{112}$ Nitekim buna benzer bir başka olay ile ilgili rivayette $\mathrm{Hz}$. Peygamber (a.s), zan ve tahminde bulunduğunu açıkça ifade etmiş ve doğan çocuk, kadının kocasını doğrulayıcı vasıfta olmasına rağmen had cezası uygulamamış, taraflara mülâane yaptırmıştır. ${ }^{113}$

110 Bkz. Hatîb el-Bağdâdî, Ebû Bekir Ahmed b. Ali b. Sâbit, Kitâbu'l-fakîh ve'l-mütefakkih, I-II, thk. Ebû Abdurrahman Âdil b. Yûsuf el-Azâzî, Dâru İbni'l-Cevzî, Riyâd, 1417/1996, I, 505.

111 Bkz. Ebû Dâvûd, Talâk 27, had. no: 2254.

112 Bkz. Nevevî, el-Minhâc, X, 112. Rivayet hakkındaki yine bu muhtevada bir açıklama İbn Abdülber tarafından $\mathrm{Hz}$. Peygamber'in, yargıda kesinliğin ve zahire göre hüküm vermenin önemi ile ilgili olarak فأقضي له على نحو ما أسمع منه "Ben de ondan duyduğuma göre onun lehine hüküm vermiş olabilirim.” şeklindeki ifadesini açıklama sadedinde yapılmıştır. Bkz. İbn Abdülber, Ebû Amr Yûsuf b. Abdullah en-Nemerî, et-Temhîd limâ fî̀l-Muvattai mine'l-meânî ve'l-esânîd, I-XXIV, thk. Mustafa b. Ahmed el-Alevî, Muhammed Abdulkebîr el-Bekrî, Müessesetü'l-Kurtuba, Magrib 1387, XXII, 219.

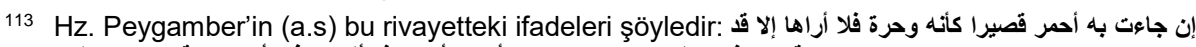
صدقت وكذب عليها وإن جاءت به أسود أعين ذا أليتين فلا أراه إلا قد صدق عليها kırmızı ve kısa bir çocuk getirirse, ben elbette kadının doğru söylemiş olduğunu ve kocasının ona iftira ettiğini düşünürüm. Eğer kadın, vücudu siyah, gözleri geniş, kalçası geniş bir çocuk doğurursa, elbette ben (Uveymir'in) bu kadına zina isnadında doğru söylediğini sanırım." Bkz. Buhârî, Talâk 30, had. no: 5309; İbn Mâce, Talâk 27, had. no: 2066; Ebû Dâvûd, Talâk 27, had. no: 2248. Bu olayda karısına zina isnâdında bulunan şahsın Ensâr'dan Uveymir adında biri olduğu nakledilmektedir. Mülâane âyetinin bu şahıs veya Hilâl b. Ümeyye hakkında indiği konusunda farklı görüşler olmakla beraber iki görüşü cem edenler de vardır. Buna göre hadise önce Hilâl b. Ümeyye tarafından yaşanmış, Uveymir'in gelişi de buna rastlamıştır. Âyet de her ikisi hakkında ve aynı zamanda inmiştir. Nevevî'nin görüşü bu yöndeyken Hatîb el-Bağdâdî, ikisinin aynı anda gelmiş olabileceğini ve yaşanmış olayın birden fazla olmasının, âyetin tek bir defada ve tamamını kapsayarak inmesine engel teşkil etmeyeceğini belirtmiştir. Bununla beraber âyetin önce Hilâl b. Ümeyye sebebi ile inmiş olması ve Hilâl'in yaşadığı olayı bilmeksizin gelen Uveymir'e Hz. Peygamber'in meselenin hükmünü bildirmiş olması da imkân dâhilindedir. Hilâl ile ilgili rivayette, "Bunun üzerine Cibrîl indi." cümlesinin, Uveymir ile ilgili rivayette ise "Allah senin hakkında şu hükmü indirdi." şeklindeki cümlenin bulunması da bunu göstermektedir. Bu son cümle de, "Senin durumunda olanlar hakkında şu hükmü indirdi." anlamıla tevil edilir. Bkz. İbn Hacer, Fethu'l-bârî, V, 716. Ayrıca bkz. Kirmânî, Muhammed b. Yûsuf b. Ali b. Saîd Şemsüddin, el-Kevâkibu'd-derârî fî şerhi Sahîhi'I-Buhârî, I-XXV, Dâru İhyâi't-Turâsi'l-Arabî, Beyrut, 1401/1981, XVIII, 7; Zürkânî, Muhammed b. Abdülbâkî b. Yûsuf, Şerhu'z-Zürkânî alâ Muvattai'l-Imâmi Mâlik, I-IV, Dâru'I-Kütübi'I-İlmiyye, Beyrut 1411, III, 245; Mubârekfûrî, Tuhfetü'l-ahvezî, IX, 28. 
Abdullah b. Şeddâd ile İbn Abbâs arasında geçen, haklarında mülâane hükmü uygulanan bir çiftle ilgili konuşmayı ihtiva eden bir rivayet de konuyla ilgili yukarıda kaydedilen rivayetlerle anlam birliğine sahip olması ve mevzu bahis olan kâidelere esas teşkil etmesi bakımından önemlidir. Buna göre Abdullah b. Şeddâd İbn Abbâs'a, Hz. Peygamber'in (a.s), "Şayet bir kimseyi delilsiz/şahitsiz olarak recm edecek olsaydım bu kadını recm ederdim." şeklindeki sözünün mülâanede bulunan bu kadın hakkında olup olmadığını sormuş, İbn Abbâs da bunun o kadın olmayıp alenî kötülük işleyen bir başka kadın olduğunu söylemiştir. ${ }^{114}$

Hz. Peygamber'in (a.s) burada söz konusu edilen ifadesi de hükümlerin kesin delillerden kaynaklanması gerektiğini, zan ve tevehhümün hüküm doğuramayacağını açıkça ortaya koyan bir başka örnektir.

6) Tayâlisî'nin Müsned'inde Ebû Hureyre'den nakledilen bir rivayet de şöyledir:

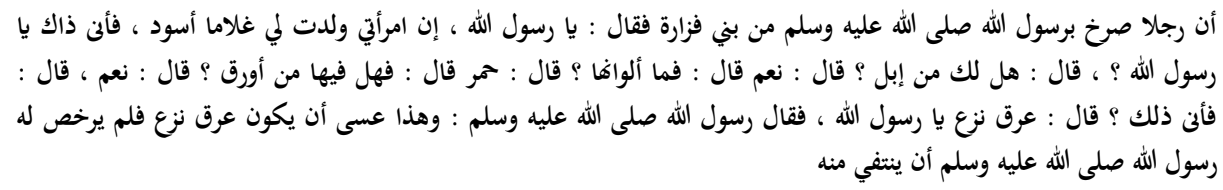

"Fezâre oğullarından bir adam ${ }^{115}$ Rasûlullah'a seslenerek (a.s) 'Yâ Rasûlallah! Karım siyah bir çocuk doğurdu. Bu nasıl olur yâ Rasûlallah?' dedi. Rasûlullah da (a.s), 'Senin develerin var mı?' diye sordu. Bedevî, 'Evet.' dedi. Rasûlullah (a.s), 'O develerin renkleri nasıldır?' diye sordu. O da, 'Kırmızıdır.' dedi. Rasûlullah (a.s), 'Bunların içinde beyazı siyaha çalar boz deve var mıdır?' dedi. O, 'Evet.' diye cevap verdi. Rasûlullah (a.s), 'Bu nereden oldu?' diye sordu. Bedevî, 'Soyunun bir damarı çekmiştir yâ Rasûlallah!' dedi. Rasûlullah da (a.s), 'Senin bu oğlun da eski bir soy köküne çekmiş olabilir!' dedi ve çocuğu reddetmesine ruhsat vermedi." 116

114 Abdurrezzak, el-Musannef, VII, 118, had. no: 12453; Buhârî, Talâk 31, had. no: 5310; Müslim, Liân 12, had. no: 1497; Nesâî, Talâk 39, had. no: 3467, 3468.

115 Ahmed b. Hanbel'in Müsned'indeki, Müslim'in Sahîh'indeki, İbn Mâce, Ebû Dâvûd, Tirmizî ve Nesâînin Sünen'lerindeki Ebû Hureyre rivayetlerinde de bu adamın Fezâre oğullarından olduğu tasrih edilmiştir. Bkz. Ahmed, Müsned, XII, 205, had. no: 7264; Müslim, Liân 18, had. no: 1500; İbn Mâce, Nikâh 58, had. no: 2002; Ebû Dâvûd, Talâk 28, had. no: 2260; Tirmizî, Velâ 4, had. no: 2128; Nesâî, Talâk 46, had. no: 3476. Ayrıca bkz. İbn Hacer, Fethu'l-bârî, VI, 504; Aynî, Umdetü'l-kârî, XX, 419. Müslim'in Sahîh'indeki bir başka rivayette ise A'râbî (çöl halkından bir adam) olarak kaydedilmiştir. Bkz. Müslim, Liân 20, had. no: 1500. Ayrıca bkz. İbn Hacer, Fethu'l-bârî, VI, 504; Aynî, Umdetü'l-kârî, XX, 419. İbn Hacer bu şahsın isminin Damdam b. Katâde olduğunu, karısının ve çocuğunun ismine ise vâkıf olamadığını belirtmiştir. Bkz. İbn Hacer, Fethu'l-bârî, VI, 504.

116 Tayâlisî, Müsned, IV, 57, had. no: 2413. Rivayetin farklı isnâd ve kısmen farklı lafızlarla yer aldığı diğer kaynaklar için bkz. Ahmed, Müsned, XII, 205, had. no: 7264, XV, 171, had. no: 9298; Buhârî, Talâk 26, had. no: 5305. Müslim, Liân 18, 20, had. no: 1500; İbn Mâce, Nikâh 
Bu rivayetin Ahmed b. Hanbel'in Müsned'indeki versiyonunun isnâdı hakkında Şuayb el-Arnaût'un değerlendirmesi Buhârî ve Müslim'in şartlarına göre sahîh olduğu yönündedir ki ${ }^{117}$ bu aynı zamanda, "Zührî- Saîd- Ebû Hureyre." şeklindeki temeli itibariyle yukarıda kaydedilen metnin de isnâdıdır. Rivayetin Ebû Dâvûd'un Sünen'indeki versiyonu da Elbânî tarafından yine sahîh olarak değerlendirilmiştir. ${ }^{118}$ Tirmizî'nin değerlendirmesi ise hasen sahîh olduğu yönündedir. ${ }^{119}$

Rivayette de görüldüğü üzere Hz. Peygamber (a.s) zan ve ihtimaller üzerine hüküm bina etmemiş ve böylelikle adamın karısına had cezası tatbik etmemiştir. Hz. Peygamber aynı zamanda adama da kazf (zina iftirası) cezası uygulamamıştır. Çünkü adam bu fiili doğrudan değil, tariz yoluyla yapmıştır. Tariz ise bir şeyi zikrederek, zikredilmeyen bir başka şeyin anlaşılmasını sağlamaktır. ${ }^{120}$ Dolayısıyla hüküm doğuracak bir kesinliğe sahip değildir. ${ }^{121}$ Nitekim Kûfe âlimlerinin ve İmam Şâfiî̀nin de, karısına tariz yoluyla zina isnâdında bulunan bu şahsa Hz. Peygamber'in (a.s) had cezasını gerekli görmediğini ortaya koyan bu rivayeti delil göstererek, tarizde had ve mülâane uygulamasının olmadığı sonucuna vardıkları nakledilmektedir. ${ }^{122}$

Nevevî de bu rivayet hakkında yaptığı yorumda, ten renkleri farklı bile olsa çocuğun babanın nesebine katılacağını, hatta baba beyaz çocuğu siyah veya bunun tam tersi de olsa durumun böyle olup sadece renkteki farklılık nedeni ile bu nesep birliğinin yok sayılmasının helal olmayacağını belirtmiştir. Yine aynı şekilde karı koca beyaz, çocuk siyah veya bunun zıddının olması durumunda da, geçmişteki bir soya çekmiş olmasının imkân dâhilinde olması

58, had. no: 2002; Ebû Dâvûd, Talâk 28, had. no: 2260; Tirmizî, Velâ 4, had. no: 2128; Nesâî, Talâk 46, had. no: 3476 .

117 Bkz. Ahmed, Müsned, XII, 206, had. no: 7264.

118 Bkz. Ebû Dâvûd, Talâk 28, had. no: 2260.

119 Bkz. Tirmizî, Velâ 4, had. no: 2128.

120 Bkz. İbn Hacer, Fethu'l-bârî, VI, 504; Azîmâbâdî, Muhammed Şemsülhak, Avnu'l-ma'bûd şerhu Süneni Ebî Dâvûd, I-XIV, Dâru'I-Kütübi'l-İlmiyye, Beyrut 1415, VI, 228.

121 Mühelleb, tarizin had cezasını gerektirmemesi için zıtlaşma ve sövme yöntemiyle değil, bilmediği bir konuyu öğrenmek amacıyla soru sorma yöntemiyle olması gerektiğini belirtmiştir. Bkz. İbn Battâl, Şerhu Sahîhi'-Buhârî, VII, 461; İbn Hacer, Fethu'l-bârî, VI, 505. İbn Kayyım da bu bilgiyi Mühelleb'e nispet etmeksizin kaydetmiştir. Bkz. İbn Kayyım el-Cevziyye, Ebû Abdullah Muhammed b. Ebû Bekr b. Eyyûb, Zâdü'l-meâd fi hedyi hayri'l-ibâd, I-V, thk. Şuayb el-Arnaût, Abdülkadir Arnaût, Müessesetü'r-Risale, Beyrut; Mektebetü'l-Menâri'l-İslâmiyye, Kuveyt 1407/1987, V, 409.

122 Bkz. İbn Battâl, Şerhu Sahîhi'l-Buhârî, VII, 461; Nevevî, el-Minhâc, X, 115; Aynî, Umdetü'lkârî, XX, 419; Azîmâbâdî, Avnu'l-ma'bûd, VI, 228. Ancak İmam Mâlik'in bu konuda farklı düşündüğü belirtilmelidir. $O$, tarizden tasrih yani açıkça söylenildiğindeki mana (kazf) anlaşıldığı sürece had ve mülâanenin gerekli olduğu görüşündedir. Bkz. İbn Battâl, Şerhu Sahîhi'l-Buhârî, VII, 461; İbn Hacer, Fethu'I-bârî VI, 505; Aynî, Umdetü'l-kârî, XX, 419. 
nedeniyle çocuğun neseben bu anne babanın sayılacağı Nevevî tarafından ifade edilmiştir. ${ }^{123}$

Nevevî'nin bu yorumu da özellikle nesebin sübutu gibi ciddi bir konuda şüphe ve tevehhümün muteber olmayıp kesin delillerin varlığının gerekliliğine dikkat çekmesi bakımından önemlidir.

\section{Sonuç}

Hz. Peygamber'in söz, davranış ve onaylamalarının ve aynı zamanda da ahlakî özelliklerinin şekillendirdiği dünya görüşü ve bundan kaynaklanan örnek yaşantı şeklinde tanımlanabilecek olan sünnetin Müslümanların bireysel ve toplumsal hayatının şekillenmesinde temel kaynaklardan biri olduğu malumdur. Bu etki doğal olarak İslâm hukukunun meydana gelmesinde de büyük ölçüde kendisini göstermiştir. İslâm hukuku hem genel prensipleri hem de furuatla ilgili bazı meseleleri itibariyle $\mathrm{Hz}$. Peygamber'in sünnetini esas olarak kabul etmiştir.

Araştırma neticesinde yukarıda bahsedilen genel durumla da ilgili olarak fıkhî hükümlerin delillerinin sahip olması gereken, kesin nitelikli olma, bir başka ifadeyle şüphe ve intimallerden uzak bulunma yönündeki temel ilkeye ve bu muhtevadaki kâidelere esas teşkil edebilecek bazı örneklerin Hz. Peygamber'in sünnetinde kavlî ve fiilî olarak yer aldığı tespit edilmiştir. Modern hukukta da önemli bir yeri olan, yargıyı somut ve kesin kanıtlar üzerine inşa etme esasının miladi 6. yüzyılda ve İslâm hukukunun temel kaynaklarından ikincisi sayılan sünnette yukarıda izah edilen boyutlarıyla yer almış olmasının hukuk bilimi ve hukuk tarihi açısından da büyük önem arz ettiği ifade edilmelidir.

Araştırmada tahlil edilen örnek rivayetler anlaşıldığı kadarıyla, "şüphehüküm ilişkisi” olarak da isimlendirilebileceği daha önce de belirtilen konuyla doğrudan alakalıdır. Nitekim kaydedilen son üç rivayetin muhtevası, ilki teorik diğerleri de pratik olmak üzere dava ve yargı süreçleri ve bunların sonucunda, kesin delillerin bulunmaması nedeniyle ortaya çıkan hükümsüzlük ile ilgilidir. İkinci ve üçüncü olarak zikredilen rivayetler ise ibadet sahasından olup burada meydana gelen şüphe ve tereddütlerin ibadetin sıhhatine zarar vermeyeceğini ve böyle bir durumda yapılması gereken şeyleri ortaya koymaktadır. Ancak bundan, ilk sırada kaydedilen ve takva ve manevî yaşantı ile ilgili olduğu da düşünülebilecek rivayet istisna edilebilir. Bu rivayetin bir yönüyle, hükme mesned teşkil edecek bilgi ve delillerde kesinlik ilkesi ile ilgili görünmediğini,

123 Nevevî, el-Minhâc, X, 115. Ayrıca bkz. Aynî, Umdetü’l-kârî, XX, 419. Bu konudaki çeşitli görüşler için bkz. İbn Hacer, Fethu'l-bârî, VI, 505. İbn Kayyım da bu rivayetin mücerred şüphe ile liân ve nesebin iptali hükmünün verilemeyeceğini gösterdiğini belirtmiştir. Bkz. İbn Kayyım el-Cevziyye, Zâdü'l-meâd, V, 409. 
hukukî boyutundan ziyade dinî hassasiyet ve ferdî huzur ile ilgili olduğunu söylemek mümkündür.

Tespit edilen rivayetlerin sıhhat durumlarının da iyi düzeyde olduğu görülmüştür. Nitekim inceleme konusu olan altı rivayetin hükmü ile ilgili olarak hadis âlimlerinin kanaatleri de genel itibariyle "sahîh" oldukları yönünde belirmiştir. Ancak dördüncü sırada zikredilen, Müslümanlardan güç yettiğince veya şüphe gibi etkenlerle cezaların düşürülmesi gerektiğini vurgulayan hadis hakkında tartışmalar olduğu ve bu rivayetin "zayıf" olduğu yönünde kanaatlerin bulunduğu da görülmüştür. Bununla beraber konuyla ilgili sahâbeden ve tabiînden nakledilen sözlerin de bulunması ve bu ilkenin her dönemde kabul görüp uygulamada kendisine yer bulması, ayrıca fakihlerin ve ümmetin genelinin bu esas üzerinde icmâ etmeleri rivayeti destekleyen unsurlar olarak görülebilir.

\section{Kaynakça}

Abd b. Humeyd, Ebû Muhammed el-Kissî (ö. 249/863), Müsned, thk. Subhî Bedrî Sâmerrâî, Mahmûd Muhammed Halîl Saîdî, Mektebetü's-Sünne, Kahire 1408/1988.

Aburrezzâk, Ebû Bekr b. Hemmâm es-San'ânî (ö. 211/826), el-Musannef, IXI, thk. Habîburrahman el-A'zamî, el-Meclisü'l-İlmî, Beyrut 1403/1983.

Aclûnî, İsmâil b. Muhammed (ö. 1162/1749), Keşfü'l-hafâ ve muzîlü'-ilbâs ammâ iştehera mine'l-ehâdîs alâ elsineti'n-nâs, Dâru İhyâi't-Türâsi'lArabî, Beyrut 1352.

Ahmed b. Hanbel, Ebû Abdullah Şeybânî (ö. 241/855), Müsned, I-L, thk. Şuayb el-Arnaût ve diğerleri, Müessesetü'r-Risâle, Beyrut 1416/1995.

Aynî, Ebû Muhammed Bedruddin Mahmûd b. Ahmed b. Musa el-Hanefî (ö. 855/1451), Umdetü'l-kârî şerhu Sahîhi'l-Buhârî, I-XXV, tsh. Abdullah Mahmûd Muhammed Ömer, Dâru'I-Kütübi'l-IImiyye, Beyrut 1421/2001.

Azîmâbâd, Muhammed Şemsülhak (ö. 1330/1911), Avnu'l-ma'bûd şerhu Süneni Ebî Dâvûd, I-XIV, Dâru'I-Kütübi'I-İlmiyye, Beyrut 1415.

Bâ Hüseyin, Yakûb b. Abdülvehhâb, el-Kavâidu'l-fıkhiyye, Mektebetü'rRüşd/Şeriketü'r-Riyâd, Riyâd 1418/1998.

Baktır, Mustafa, "Kâide”, DIA, XXIV, ss. 205-210, İstanbul 2001.

Beyhakî, Ebû Bekir Ahmed b. Hüseyin b. Ali b. Mûsâ (ö. 458/1066), esSünenü'l-kübrâ, I-X, Meclisü Dâirati'l-Maârifi'n-Nizâmiyye, Haydarâbâd, 1344.

Bezzâr, Ebû Bekir Ahmed b. Amr b. Abdulhâlık el-Atekî (ö. 292/904), Müsnedü'I-Bezzâr (Bahru'z-zehhâr), I-XVIII, (thk. Mahfûzurrahman Zeynullah, Âdil b. Sa'd, Sabrî Abdulhâlık eş-Şâfiî), Mektebetü'l-Ulûm ve'l-Hikem, Medîne, 1988-2009. 
Bilmen, Ömer Nasuhi, Hukuku İslamiyye ve Istılâhâtı Fıkhiyye Kâmûsu, I-VIII, Bilmen Yayın Evi, İstanbul 1967.

Buhârî, Muhammed b. İsmail (ö. 256/870), el-Cami'u's-sahîh, Dâru's-Selâm, Riyad 1999.

Burnû, Muhammed Sıdkî b. Ahmed, Mevsûatü'l-kavâidi'l-fıkhiyye, I-XII, Mektebetü't-Tevbe/Dâru İbn Hazm/Müessesetü'r-Risâle, Riyad/Beyrut, 1997/1418, 2000/1421, 2003/1424.

Dârekutnî, Ali b. Ömer (ö. 385/995), Sünen, I-V, (thk. Şuayb el-Arnaût, Hasen Abdülmün'im Şelebî, Abdullatif Hırzallah, Ahmed Berhûm), Müessesetü'r-Risâle, Beyrut 1424/2004.

Dârimî, Ebû Muhammed Abdullah Abdurrahman (ö. 255/869), Sünen, I-II, Çağrı Yay. ve Dâru Sehnûn, İstanbul 1413/1992.

Debûsî, Ebû Zeyd Ubeydullah b. Îsâ el-Hanefî (ö. 430/1039), Te's'isu'n-nazar, (thk. Mustafa Muhammed el-Kabbânî ed-Dımeşkî), Dâru İbn Zeydûn, Beyrut/ Mektebetü'l-Külliyyâti'l-Ezheriyye, Kahire trs.

Ebû Avâne, Ya'kûb b. İshâk el-İsferâinî (ö. 316/928), Müsnedü Ebî Avâne, I-V, Dâru'l-Ma'rife, Beyrut, trs.

Ebû Dâvûd, Süleyman b. el-Eş'as es-Sicistânî (ö. 275/889), Sünen, Dâru İbni'l-Cevzî, Kahire 1432/2011.

Ebû Hanîfe, Nu'mân b. Sâbit (ö. 150), Müsnedü Ebî Hanîfe, (thk. Ebû Muhammed el-Asyûtî), Dâru'l-Kütübi'l-İlmiyye, Beyrut 2008.

Ebû Ya'lâ, Ahmed b. Ali b. el-Müsennâ el-Mûsulî (ö. 307/919), Müsnedü Ebî Ya'lâ, I-XIII, thk. Hüseyin Selîm Esed, Dâru'l-Me'mûn li't-Turâs, Dımeşk 1404/1984.

Elbânî, Muhammed Nâsıruddin, İrvâu'l-ğalîl fî tahrîci ehâdîsi Menâri's-sebîl, IVIII, Mektebu'l-İslâmî, Beyrut 1405/1985.

Erdoğan, Mehmet, Fıkıh ve Hukuk Terimleri Sözlüğü, Rağbet Yay., İstanbul 1998.

Gür, A. Refik, Hukuk Tarihi ve Tefekkürü Bakımından Mecelle, Sebil Yay., İstanbul 1993.

Hâdimî, Ebû Saîd Muhammed (ö. 1176/1762), Mecâmiu'l-hakâik, Mahmud Bey Matbaası, byy., 1318.

Hâkim, Muhammed b. Abdullah en-Nisâburî (ö. 405/1014), el-Müstedrek ale's-Sahîhayn, I-IV, Dâru'l-Kütübi'I-İlmiyye, Beyrut 1411/1990.

Hatîb el-Bağdâdî, Ebû Bekir Ahmed b. Ali b. Sâbit (ö. 463/1071), Kitâbu'l-fakîh ve'l-mütefakkih, I-Il, thk. Ebû Abdurrahman Âdil b. Yûsuf el-Azâzî, Dâru İbni'l-Cevzî, Riyâd, 1417/1996.

Haydar, Ali (ö. 1354/1935), Dürerü'l-hükkâm şerhu Mecelleti'l-ahkâm, I-IV, Dâru Âlemi'l-Kütüb, Riyad 1423/2003. 
Humeydî, Ebû Bekir Abdullah b. Zübeyr b. Îsâ b. Ubeydullah (ö. 219/834), Müsnedü'l-Humeydî, I-II, thk. Hasan Selîm Esed ed-Dârânî, Dâru'sSekâ, Dimeşk, 1996.

İbn Abdülber, Ebû Amr Yûsuf b. Abdullah en-Nemerî (ö. 463/1071), el-İstizkâr, I-VIII, (thk. Sâlim Muhammed Atâ, Muhammed Ali Muavvad), Dâru'lKütübi'l-IIlmiyye, Beyrut, 1421/2000.

., et-Temhîd limâ fî'I-Muvattai mine'I-meânî ve'l-esânîd, I-XXIV, (thk. Mustafa b. Ahmed el-Alevî, Muhammed Abdulkebîr el-Bekrî), Müessesetü'l-Kurtuba, Magrib 1387.

İbn Battâl, Ebu'l-Hasen Ali b. Halef b. Abdülmelik (ö. 449/1057), Şerhu Sahîhi'l-Buhârî, I-X, (thk. Ebû Temîm Yâsir b. İbrahim), Mektebetü'rRüşd, Riyâd, 1423/2003.

İbn Ebû Şeybe, Ebû Bekir Abdullah b. Muhammed (ö. 235/849), el-Musannef, I-XXI, (thk. Muhammed Avvâme), Dâru'l-Kıble, byy., trs.

İbn Hacer, Şihâbeddin Ahmed b. Ali b. Muhammed b. Ahmed Askalânî (ö. 852/1449), ed-Dirâye fî tahrîci ehâdîsi'l-Hidâye, I-Il, (thk. Seyyid Abdullah Hâşim el-Yemânî el-Medenî), Dâru'I-Ma'rife, Beyrut, trs. ., Fethu'I-bârî şerhu Sahîhi'I-Buhârî, I-VIII, Dâru'I-Marife, Beyrut 2005. Tehzîbu't-Tehzîb, I-IV, Müessesetü'r-Risâle, Beyrut 1995.

Takrîbu't-Tehzîb, I-II, Dâru'I-Kütübi'I-IIImiyye, Beyrut 1415/1995.

İbn Mâce, Ebû Abdullah Muhammed b. Yezid el-Kazvînî (ö. 273/886), Sünen, I-II, Çağrı Yay. ve Dâru Sehnûn, İstanbul 1413/1992.

İbn Kayyım el-Cevziyye, Ebû Abdullah Muhammed b. Ebû Bekr b. Eyyûb (ö. 751/1351), Zâdü'l-meâd fi hedyi hayri'l-ibâd, I-V, (thk. Şuayb el-Arnaût, Abdülkadir el-Arnaût), Müessesetü'r-Risale, Beyrut; Mektebetü'lMenâri'l-İslâmiyye, Kuveyt 1407/1987.

İbn Receb, Zeynüddin Ebû'l-Ferec Abdurrahman b. Şihâbüddin el-Hanbelî elBağdâdî ed-Dımeşkî (ö. 795/1393), Fethu'I-bârî şerhu Sahîhi'l-Buhârî, IVI, (thk. Ebû Muâz Târık b. Avdullah b. Muhammed), Dâru İbni'l-Cevzî, es-Suûdiyye/Demmâm 1422.

İbn Selâme, Ebû İslâm Mustafa b. Muhammed, et-Te'sîsu fî usûli'l-fıkhi alâ dav'i'l-kitâbi ve's-sünne, Mektebetü'l-Harameyni li'I-Ulûmi'n-Nâfia, byy., trs.

İbnü'l-Kâss, Ebû'l-Abbâs Ahmed b. Ebû Ahmed et-Taberî (ö. 335/946), etTelhîs, (thk. Âdil Ahmed Abdulmevcûd, Ali Muhammed Muavvad), Mektebetü Nizâr Mustafâ el-Bâz, byy., trs.

İbn Nüceym, Zeynuddin b. İbrahim b. Muhammed (ö. 970/1563), el-Eşbâh ve'n-nezâir, thk. Muhammed Mutî' el-Hâfız, Dâru'l-Fikr, Dımeşk 1983.

Karâfî, Şihâbuddin Ebû'l-Abbâs Ahmed b. İdrîs el-Mısrî el-Mâlikî (ö. 684/1285), el-Furûk, I-IV, (thk. Ömer Hasen el-Kıyyâm), Müessesetü'rRisale, Beyrut 1424/2003. 
Kirmânî, Muhammed b. Yûsuf b. Ali b. Saîd Şemsüddin (ö. 786/1384), elKevâkibu'd-derârî fî şerhi Sahîhi'l-Buhârî, I-XXV, Dâru İhyâi't-Turâsi'lArabî, Beyrut, 1401/1981.

Mâlik b. Enes, Ebû Abdullâh İbn Mâlik b. Ebû Âmir el-Asbahî el-Yemenî (ö. 179/795), el-Muvatta', I-II, Çağrı Yayınları ve Dâru Sehnûn, İstanbul 1413/1992.

Mecelle-i Ahkâm-ı Adliyye Cemiyeti, Mecelle-i Ahkâm-i Adliyye, Matbaa-i Osmaniye, İstanbul 1300/1882.

Mesûd Efendi (ö. 1311/1894), Mirât-ı Mecelle, Matbaa-i Osmaniye, Dersaâdet $1302 / 1884$.

Mizzî, Cemalüddin Ebû Haccac Yusuf (ö. 742/1342), Tehzîbu'l-Kemâl fi esmâi'r-ricâl, I-XXXV, thk. Beşşâr Avvâd Maruf, Müessesetü'r-Risâle, Beyrut 1403/1983.

Mübârekfûrî, Ebû'l-Ulâ Muhammed Abdurrahman b. Abdurrahim (ö. 1353/1935), Tuhfetü'l-ahvezî bi şerhi Câmi'i't-Tirmizî, I-X, (tsh. Abdurrahman Muhammed Osman), Dâru'l-Fikr, Beyrut trs.

Müslim, Ebû'l-Huseyn Müslim b. Haccâc (ö. 261/875), el-Câmiu's-sahîh, I-III, Çağrı Yay. ve Dâru Sehnûn, İstanbul 1413/1992.

Nedvî, Ali Ahmed, el-Kavâidu'l-fıkhiyye, (tkd. Mustafa ez-Zerkâ), Dâru'lKalem, Dımeşk 1412/1991.

Nesâî, Ebû Abdurrahman Ahmed b. Şuayb b. Ali el-Horâsânî (ö. 303/915), Sünen, tsh. Ahmed Şemsüddin, Dâru'l-Kütübi'l-IImiyye, Beyrut 2009.

Nevevî, Ebu Zekeriyya Yahya b. Şeref (ö. 676/1278), el-Minhâc şerhu Sahîhi Müslim b. el-Haccâc, I-XVIII, Dâru'I-Gaddi'l-Cedîd, Kâhire 1429/2008.

Özafşar, Mehmet Emin, Hadisi Yeniden Düşünmek, Ankara Okulu Yay., Ankara 2000.

Öztürk, Osman, Osmanlı Hukuk Tarihinde Mecelle, İslâmî İlimler Araştırma Vakfı Neşriyatı, İstanbul 1973.

Pezdevî, Ali b. Muhammed el-Hanefî (ö. 482/1089), Kenzu'l-vusûl ilâ ma'rifeti'l-usûl, Matbaatu Câvîd Büryes, Karaçi trs.

San'ânî, Muhammed b. İsmail el-Emîr el-Kehlânî (ö. 1182/1768), Sübülü'sselâm, I-IV, Mektebetü Mustafâ el-Bâbî el-Halebî, byy. 1379/1960.

Serahsî, Muhammed b. Ahmed (ö. 483/1090), Usûlü's-Serahsî, I-II, Dâru'lKütübi'l-İlmiyye, Beyrut 1414/1993.

el-Mebsût, I-XXX, Dâru'I-Ma'rife, Beyrut 1414/1993.

Sîrvân, Abdülaziz, et-Tibyân bi şerhi mâ't-tefeka aleyhi'ş-Şeyhân, I-III, Dâru'rReşîd, Dımeşk-Beyrut 1413/1992.

Şafak, Ali, "Hukukun Temelleri Açısından Mecelle'ye Bir Bakış”, Ahmet Cevdet Paşa (1823-1895), (Sempozyum: 9-11 Haziran 1995), TDV Yay., Ankara 1997, ss. 263-278. 
Sübkî, Tâcüddin Abdulvehhâb b. Ali b. Abdulkâfî (ö. 771/1370), el-Eşbâh ve’nnezâir, I-II, (thk. Âdil Ahmed Abdulmevcûd), Dârü'l-Kütübi'l-İlmiyye, Beyrut 1411/1991.

Süyûtî, Celaleddin Abdurrahman (ö. 911/1505), el-Eşbâh ve’n-nezâir fî kavâidi ve furûi fıkhi'ş-Şâfiiyye, I-II, Mektebetü Nizâr Mustafa el-Bâz, Mekke/Riyâd 1418/1997.

Tedrîbü'r-râvî fî şerhi Takrîbi'n-Nevevî, Dâru İbn Hazm, Beyrut 1430/2009.

Taberânî, Ebû'l-Kâsım Süleyman b. Ahmed (ö. 360/971), el-Mu'cemu'l-kebîr, I-XX, (thk. Hamdî b. Abdülmecîd Selefî), Mektebetü'l-Ulûm ve'l-Hikem, Musul 1404/1983.

Tânevî, Zafer Ahmed el-Osmânî (ö. 1974), I'lâu's-sünen, I-XXI, Dâru'I-Fikr, Beyrut, 1421/2001.

Tayâlisî, Ebû Dâvûd Süleyman b. Dâvûd b. el-Cârûd (ö. 204/820), Müsned, IIV, thk. Muhammed b. Abdulmuhsin et-Türkî, Dâru Hicr, Mısır, 1419/1999.

Tirmizî, Ebû Îsâ Muhammed b. Îsâ b. Sevre (ö. 279/892), Câmi'u't-Tirmizî, Dâru's-Selâm, Riyâd 1999.

Tuzcu, Abdullah, Kur'ân-ı Kerîm Açısından Mecelle'nin Küllî Kaideleri, (Yayımlanmamış Yüksek Lisans Tezi), Atatürk Üniversitesi Sosyal Bilimler Enstitüsü, Erzurum 2012.

Yıldırım, Mustafa, Mecelle'nin Küllî Kâideleri, İzmir İlahiyat Fakültesi Vakfı Yay., İzmir 2001.

Zerkâ, Ahmed b. Muhammed (ö. 1357/1938), Şerhu'l-kavâidi'l-fıkhıyye, (thk. Mustafa Ahmed Zerkâ), Dâru'l-Kalem, Dımeşk, 1409/1989.

Zeylaî, Abdullah b. Yûsuf (ö. 762/1360), Nasbu'r-râye li-ehâdîsi'l-Hidâye, I-V, (thk. Muhammed Avâme), Müessesetü'r-Reyyân, Cidde, 1418/1997.

Zuhaylî, Muhammed Mustafa, el-Kavâidu'l-fıkhiyye ve tatbîkâtuhâ fî̀mezâhibi'l-erbaa, I-II, Dâru'l-Fikr, Dımaşk 1430/2009.

Zürkânî, Muhammed b. Abdülbâkî b. Yûsuf, (ö. 1122/1710), Şerhu'z-Zürkânî alâ Muvattai'I-Imâmi Mâlik, I-IV, Dâru'I-Kütübi'l-İlmiyye, Beyrut 1411. 


\section{The Fundemantals of "The Principles of Islamic Jurisprudence" (Kawaid al-Fiqhiyya) in the Ahadith (Traditions), that Envisage the Certainty (Yaqeen) in the Information and Evidence of Legal Rules}

Citation / (C)- Çelikan, S. (2018). The Fundemantals of "The Principles of Islamic Jurisprudence" (Kawaid al-Fiqhiyya) in the Ahadith (Traditions), that Envisage the Certainty (Yaqeen) in the Information and Evidence of Legal Rules, Çukurova University Journal of Faculty of Divinity, 18 (1), 361-389.

Abstract- It is essential that the knowledge and evidence that determine the decisions in all human activities, from the Islamic worship to legal processes, are of certain quality. This is an important condition for achieving correct and fair results. Hence, it is not possible to take the evidence, which is not free of existence of doubt and different probabilities as a basis for decision-making and judgment. This important point has also been found among "the principles of Islamic jurisprudence" which is also known as kawaid al-fiqhiyya in the form of various articles. Considering that the time of Prophet Muhammad was the first application area of Islamic law, it is not hard to conjecture that the fundemantals of the socalled principle and thus the principles of Islamic jurisprudence which propound this principle in different forms, may also exist in this period. As a matter of fact, studies on hadith sources reveal that there are various examples of verbal and actual traditions (sunnah) in this subject which can also be called as doubt-judgment relation. The aim of this study is to identify this examples, theirs reliability and relation the basis of the issue.

Keywords- Islamic jurisprudence, legal rules, sources of hadith, traditions (sunnah), relation of doubt and judgment 